CIOMARA DE FREITAS GONÇALVES

\title{
As Casas de Apoio no contexto das políticas públicas de saúde para as DST/HIV/Aids no Estado de São Paulo, no período de 1996 a 2003
}

\author{
Dissertação apresentada à Faculdade de \\ Medicina da Universidade de São Paulo, para \\ obtenção do título de Mestre em Medicina \\ Preventiva.
}

Área de Concentração: Medicina Preventiva

Orientador: Prof. Dr. Heráclito Barbosa de Carvalho 
CIOMARA DE FREITAS GONÇALVES

\title{
As Casas de Apoio no contexto das políticas públicas de saúde para as DST/HIV/Aids no Estado de São Paulo, no período de 1996 a 2003
}

\author{
Dissertação apresentada à Faculdade de \\ Medicina da Universidade de São Paulo, para \\ obtenção do título de Mestre em Medicina \\ Preventiva.
}

Área de Concentração: Medicina Preventiva

Orientador: Prof. Dr. Heráclito Barbosa de Carvalho 


\section{As Casas de Apoio no contexto das políticas públicas de saúde para as DST/HIV/Aids no Estado de São Paulo, no período de 1996 a 2003}

Dissertação apresentada à Faculdade de Medicina da Universidade de São Paulo, para obtenção do título de Mestre em Medicina Preventiva.

Área de Concentração: Medicina Preventiva

Orientador: Prof. Dr. Heráclito Barbosa de Carvalho

Aprovado em:

Banca Examinadora

Prof. Dr.

Instituição:

Assinatura:

Prof. Dr.

Instituição:

Assinatura:

Prof. Dr.

Instituição:

Assinatura:

Prof. Dr.

Instituição:

Assinatura:

Prof. Dr.

Instituição:

Assinatura:

Prof. Dr.

Instituição:

Assinatura: 


\section{AGRADECIMENTOS}

Ao meu orientador, professor Heráclito Barbosa Carvalho, por ter aceitado o desafio de me apoiar neste trabalho, conduzindo-me sempre de maneira amável e tranqüila, compreendendo e aceitando os meus limites de aprendiz.

À professora Ana Luisa D’Avila Viana, que acompanhou este trabalho desde o início e contribuiu de forma muito significativa, dando-me segurança e estímulo.

A professora Márcia Thereza Couto, por sua valiosa ajuda nas questões metodológicas.

Tenho uma enorme gratidão à Analice de Oliveira, assistente social do CRTDST/AIDS, minha amiga, que me ajudou enormemente a reunir e corrigir dados sobre as Casas de Apoio e foi cúmplice em todas as dificuldades pelas quais passei para concretizar este trabalho, cuja ajuda jamais poderei esquecer.

Aos colegas do Programa Estadual de DST/Aids de São Paulo, em especial a Vilma Cervantes, que possibilitou a minha mudança para São Paulo e sempre me incentivou a fazer este mestrado, ajudando-me em momentos muito difíceis.

À Maria Clara Giana (CRT-DST/AIDS de São Paulo), Rubens Duda (Fórum ONGs/Aids), Silvana Hengles (Programa Municipal de DST/Aids de São Paulo) e Paulo Teixeira (médico, ex-coordenador do Programa Nacional de DST e Aids), pelas entrevistas concedidas e pela disponibilidade para esclarecimentos e outras formas de ajuda.

A Ernesto Negris, meu gerente na PETROBRAS, pela enorme compreensão e generosidade que possibilitaram a continuação deste estudo.

A Andréa Vasconcelos, Bela Feiman S. Silva, Cecília Sartório Altoé, Luiz Marcelo da Rós, Marilena Schiavin, Sandra Camisão Nogueira, e a tantos outros 
amigos queridos que, com sua paciência e apoio variados, me estimularam a continuar.

À Maria Tereza Costa Guimarães, que me enviou muitos textos, artigos, livros, um material excepcional, fundamental para o meu estudo.

Deixei em São Paulo pessoas especiais, ativistas do movimento de luta contra a Aids que, com seu trabalho, me inspiraram a produzir esta dissertação. São muitos, mas não posso deixar de citar Duda, Eduardo e Gil.

Agradeço, de modo especial, à minha família, irmãs e irmãos, pelo apoio incondicional, a qualquer tempo e de todas as maneiras possíveis, sempre com muito amor.

A Gabriel Torres e Edna, por me ajudarem na resolução dos problemas de digitação dos dados.

A Dra. Carla Fossi Scopel, minha terapeuta e grande incentivadora, pelo suporte emocional fantástico nesse período de muitos desafios simultâneos.

A todos os que leram e releram meus escritos, enviando-me documentos e livros, e que de alguma forma me ajudaram a materializar este sonho. 
Aos meus pais, Osias e Grassuita, que sempre afirmaram que a única herança que poderiam deixar para os filhos eram "os estudos". E por essa herança eu serei imensamente grata, por toda a minha vida. 


\section{RESUMO}

Gonçalves CF. As casas de apoio no contexto das políticas públicas de saúde para as DST/HIV/AIDS no Estado de São Paulo, no período de 1996 a 2003 [dissertação] São Paulo: Faculdade de Medicina, Universidade de São Paulo; 2006. 106 p.

As Casas de Apoio são instituições que oferecem atenção às pessoas com HIV/Aids e que, por motivos de natureza social, necessitam de cuidados e de moradia provisória ou permanente. Oferecem atendimento às necessidades básicas do indivíduo e suporte à sua condição de soropositividade como garantia de manutenção do tratamento, inserção familiar, apoio com relação aos direitos sociais e trabalhistas, lazer e apoio psicológico. Este estudo se utiliza da triangulação de métodos qualitativos e quantitativos, por meio de diferentes técnicas, para caracterizar as Casas de Apoio em HIV/Aids do Estado de São Paulo e analisar sua inserção como modalidade de rede de apoio assistencial, contextualizando as Organizações Não-Governamentais no âmbito das políticas públicas de saúde para - HIV/Aids. O estudo em curso registra uma concentração de casas localizadas na Capital. No aspecto de sustentabilidade, a captação de recursos é diversificada, com recursos públicos governamentais, financiamento de organismos internacionais, doações de pessoas físicas e apoio comunitário. As Casas de Apoio, fruto da organização da sociedade civil, representam um grande esforço da comunidade para garantir o atendimento às diferentes necessidades das pessoas portadoras do HIV/Aids, em especial nos aspectos psíquicos e sociais. Essas organizações têm sido utilizadas pelo sistema de saúde como referência de apoio à rede de assistência a soropositivos e doentes de aids, se não de maneira formal, pelo menos informal. A sua inserção na rede de financiamentos do SUS pode representar um grande avanço na formalização de uma ação intersetorial que já ocorre de fato, otimizando a utilização de recursos, qualificando os serviços oferecidos, ao mesmo tempo em que maximiza os resultados dos investimentos públicos feitos no enfrentamento das DST/Aids.

Palavras-chave: Ação Intersetorial. Organizações Não Governamentais. Apoio Social. Política de Saúde. HIV. Síndrome de Imunodeficiência Adquirida. 


\begin{abstract}
Gonçalves CF. Support House in the context of health public policies for STD, HIV and AIDS in the state of São Paulo from 1996 to 2003 [Dissertation] São Paulo: "Faculdade de Medicina, Universidade de São Paulo"; 2006. 106p.

The so called Support Houses are institutions that give attention to the HIV/Aids individuals and who, due to reasons of social nature, are in need of care and provisory or permanent housing. They assist the basic necessities of the people and give support to their living condition of HIV positive patients as a guarantee of treatment, familiar insertion, social and working rights support, entertainment and psychological support. This study uses the triangulation of qualitative and quantitative methods, through different techniques, to characterize the HIV/Aids Support Houses in the state of São Paulo and to analyze its insertion as modality of assistance support net, contextualizing the Non-Governmental Organizations in the ambit of health public politics for the HIV/Aids. The study in course registers a concentration of houses located in the capital city. In the sustainability aspect, the fund raising is diversified, with governmental public resources, financing of international organisms, people's donation and community support. The Support Houses, a result of the civil society organization, represent a great effort of the community to guarantee the assistance of different necessities of HIV/Aids patients, mainly in the psychic and social aspects. These organizations have been used by the health system as support reference to the net of assistance to HIV patients and individuals, if not in a formal way, at least in an informal one. Its insertion in the net of SUS financing may represent a great advance in the formalization of an intersectional action that is already a fact, optimizing the use of resources, qualifying the services offered, at the same time that the results of public financing made for STD/Aids are maximized.
\end{abstract}

Descriptors: Intersectorial Action. Non Governmental Organizations. Social Support. Health Policy. HIV. Acquired Immunodeficiency Syndrome 


\section{LISTA DE TABELAS}

Tabela 1. Localização geográfica das Casas de Apoio em HIV/Aids no Brasil....59

Tabela 2. Casas de Apoio segundo Capital, Região Metropolitana e municípios

do interior.

Tabela 3. Número de Casas de Apoio por município.

Tabela 4. Organização jurídico-administrativa de Casas de Apóio do Estado de São Paulo.

Tabela 5. Bens de Casas de Apoio do Estado de São Paulo. 65

Tabela 6. Fontes de recursos às Casas de Apoio do Estado de São Paulo. .......66

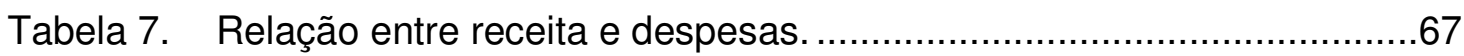

Tabela 8. Características da população atendida. ...........................................68

Tabela 9. Procedência dos usuários segundo tipos de encaminhamento.............69

Tabela 10. Capacidade de atendimento segundo número de camas disponíveis, número de atendimentos/mês e tipo de permanência.

Tabela 11. Características assistenciais segundo apoio às necessidades do diaa-dia, atendimentos de saúde e atividades oferecidos aos usuários das Casas de Apoio do Estado de São Paulo

Tabela 12. Quadro de profissionais das Casas de Apoio do Estado de São Paulo. .74

Tabela 13. Avaliação externa e principais dificuldades de Casas de Apoio do Estado de São Paulo. 


\title{
LISTA DE SIGLAS
}

\author{
ARV Anti-Retrovirais \\ BIRD Banco Internacional para a Reconstrução e Desenvolvimento \\ CAMS Comissão Nacional de Articulação dos Movimentos Sociais \\ CIS Comissão Interinstitucional de Saúde do Estado \\ CM DST/AIDS Coordenação Municipal de DST/AIDS \\ CNAIDS Comissão Nacional de Aids \\ CONASEMS Conselho Nacional de Secretários Municipais de Saúde \\ CONASS Conselho Nacional de Secretários Estaduais de Saúde \\ CRT-A Centro de Referência e Treinamento em Aids \\ CRT-DST/AIDS Centro de Referência e Treinamento em Doenças Sexualmente \\ Transmissíveis e AIDS \\ DHDS Divisão de Hansenologia e Dermatologia Sanitária \\ DIR Direção Regional de Saúde \\ DST Doenças Sexualmente Transmissíveis \\ FEBEM Fundação Estadual do Bem-Estar do Menor \\ GLTTB Gays, Lésbicas, Transgêneros, Travestis e Bissexuais \\ GOA Grupo Operativo Assessor \\ GT OG/ONG Grupo de Trabalho de Organizações Não-Governamentais e \\ Organizações Governamentais \\ HIV Síndrome de Imunodeficiência Adquirida \\ INAMPS Instituto Nacional de Assistência Médica da Previdência Social \\ MOPAIDS Movimento Paulistano de Articulação e Luta contra a AIDS
}


$O G$

Organizações Governamentais

OMS Organização Mundial de Saúde

ONGs Organizações Não Governamentais

OPAS Organização Pan-americana de Saúde

OSC Organização da Sociedade Civil

OSCIP Organização da Sociedade Civil de Interesse Público

PAM Plano de Ações e Metas

PE DST/AIDS Programa Estadual de DST/Aids

PM DST/AIDS Programa Municipal de DST / Aids

PN-DST/AIDS Programa Nacional de DST e Aids

RNP Rede Nacional de Pessoas Vivendo com HIV/Aids

SAE Serviço de Atendimento Especializado

SCDH Unidade de Sociedade Civil e Direitos Humanos

SESSP Secretaria de Estado da Saúde de São Paulo

SIDA Síndrome da Imunodeficiência Adquirida

SIM Sistema de Informação de Mortalidade

SINAN Sistema de Informação de Agravos de Notificação

SUDS Sistema Unificado e Descentralizado de Saúde

SUS Sistema Único de Saúde

UDI Usuário de Drogas Injetáveis

UNESCO Organização das Nações Unidas para a educação, a ciência e a cultura 


\section{SUMÁRIO}

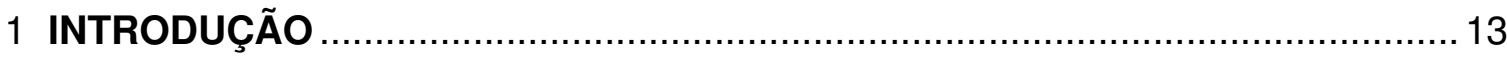

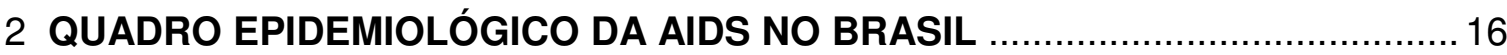

3 AS POLÍTICAS DE SAÚDE PARA AS DST/AIDS NO BRASIL ........................ 19

4 CONSIDERAÇÕES SOBRE O CONTEXTO SOCIAL E POLÍTICO DA AIDS E

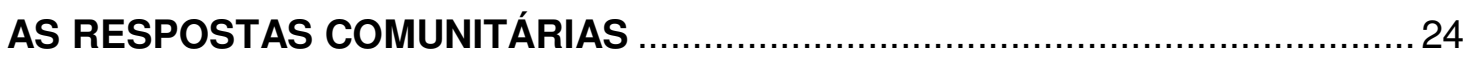

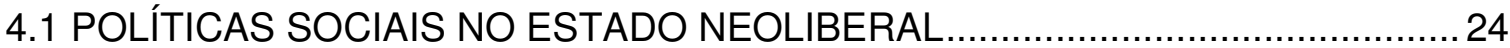

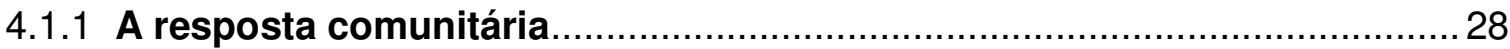

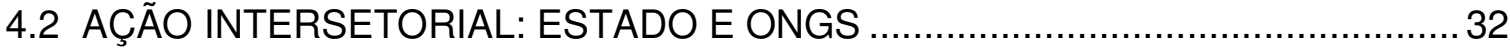

5 POLÍTICAS EM DST/AIDS NO ESTADO DE SÃO PAULO ............................. 35

6 AÇÃO INTERSETORIAL NO CAMPO DAS DST/AIDS ............................. 39

6.1 A EXPERIÊNCIA DO ESTADO DE SÃO PAULO ....................................... 39

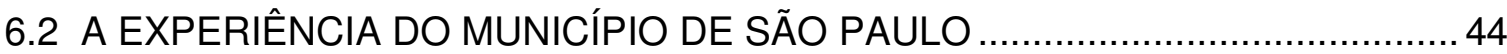

6.3 A INTERSETORIALIDADE SOB A PERSPECTIVA DAS ONGS/AIDS ............. 47

6.3.1 A participação das Casas de Apoio nos espaços de articulação

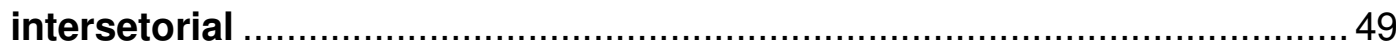

6.4 ESTRATÉGIAS DE INCORPORAÇÃO DAS DEMANDAS DA SOCIEDADE CIVIL ORGANIZADA NAS POLÍTICAS PÚBLICAS PARA AS DST/HIV/AIDS .....51 6.5 INTERAÇÃO DO GESTOR ESTADUAL DO SUS COM ORGANISMOS

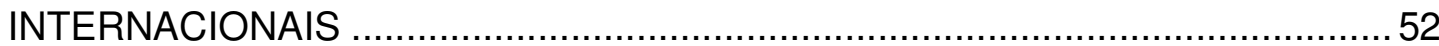

6.6 RELEVÂNCIA DAS CASAS DE APOIO NO CONTEXTO DA ASSISTÊNCIA ÀS PESSOAS PORTADORAS DE HIV NO ESTADO DE SÃO PAULO ..................... 52

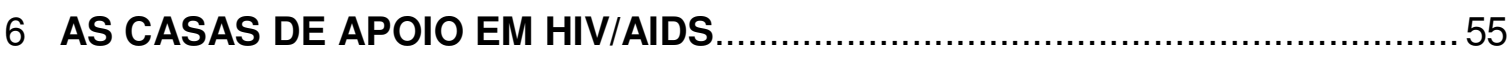

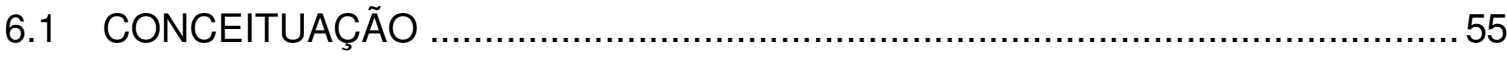


7.2 DISTRIBUIÇÃO DAS CASAS DE APOIO NO BRASIL ....................................58

6.3.1 Distribuição geográfica das Casas de Apoio no Estado de São Paulo ........61

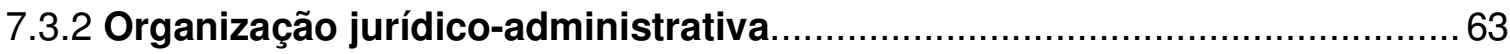

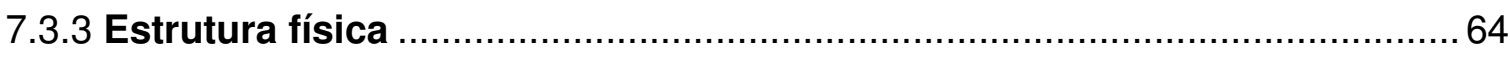

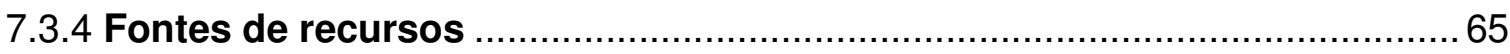

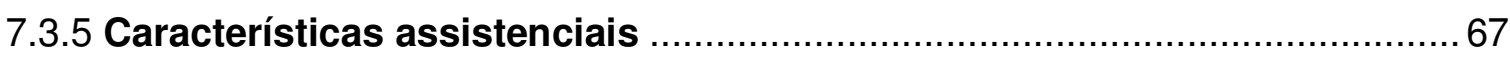

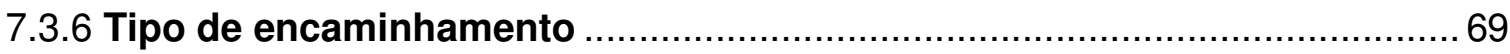

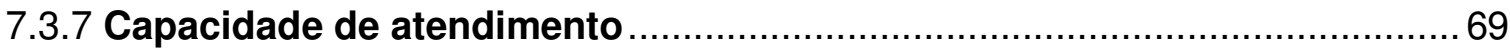

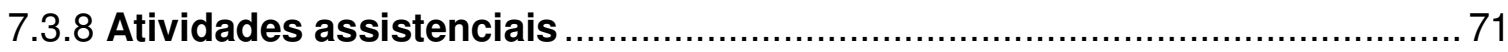

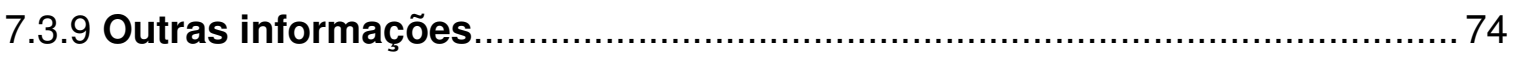

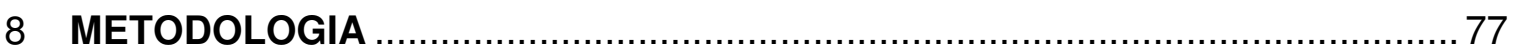

8.1 BANCO DE DADOS DAS CASAS DE APOIO ……….................................. 77

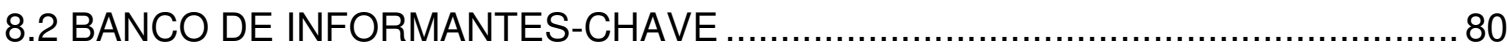

8.3 LEVANTAMENTO BIBLIOGRÁFICO E DOCUMENTAL ........................................ 81

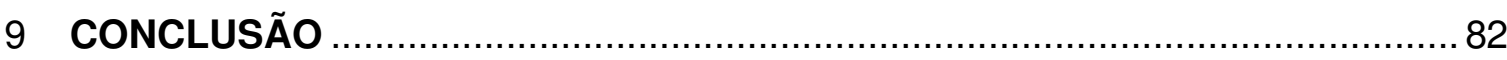

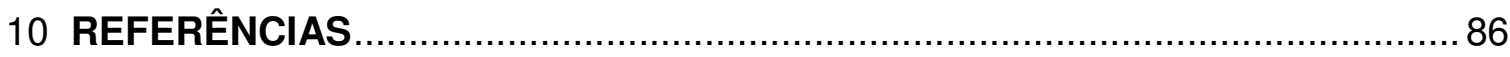

ANEXOS 


\section{INTRODUÇÃo}

Quando a aids foi identificada, no início dos anos 80, o grupo populacional mais atingido, em todo o mundo, foi o de homossexuais masculinos. Associada à sexualidade, à transgressão e à morte, a aids evidenciou velhos dilemas morais da sociedade, o que, juntamente com a dimensão trágica com que era disseminada, provocou a chamada morte civil ${ }^{1}$ de muitos dos soropositivos. Impulsionados pela vivência ampliada do estigma e do preconceito que os afetavam, os homossexuais protagonizaram luta por uma resposta governamental no enfrentamento da epidemia e, por meio de ampla mobilização e ativismo político, criaram estratégias inovadoras no âmbito da prevenção, lutaram por respostas terapêuticas, pela defesa dos direitos humanos, da livre orientação sexual, pela cidadania e, principalmente, (re)significaram e reacenderam a solidariedade.

No Brasil, a solidariedade aos homossexuais portadores do HIV foi incorporada à agenda política do movimento homossexual brasileiro. Programas governamentais e projetos de organizações não-governamentais, direcionados para os homossexuais, foram implantados para conter o avanço da epidemia, numa parceria que se consolidou desde o início da implantação do Programa Nacional de DST e Aids.

Pode-se dizer que o Estado reconheceu o desafio que ora se apresentava como um problema que necessitava da atenção pública. Como assinalam Meny e Thonig (1992), uma política pública não nasce casualmente, mas de necessidades

1 Expressão originária do Código Civil Brasileiro, de 1916, e que se refere à morte presumida de uma pessoa desaparecida. Nas legislações antigas, a pena imputada às pessoas condenadas por crimes graves era a reputação como civilmente mortos e a conseqüente perda de seus direitos civis e políticos (VENOSO, 2003). Essa expressão foi muito utilizada pelo sociólogo brasileiro Herbert Daniel que afirmava que o preconceito contra as pessoas portadoras do HIV/Aids as impedia de usufruir dos seus direitos humanos básicos, condenado-as à morte civil. 
que não podem ser desconsideradas pelas autoridades públicas. O problema da aids no Brasil tornou-se, inevitavelmente, tema de uma agenda institucional, como conseqüência das pressões das pessoas afetadas, direta ou indiretamente, pelo vírus da aids e também da pressão dos profissionais de saúde.

A capacidade de articulação da sociedade civil - em especial a das organizações que têm como principal missão a militância no âmbito do HIV/Aids entre si e entre as várias instâncias de governo, tem sido amplamente explorada como estratégia de fortalecimento dos mecanismos de controle social. Com iniciativas voltadas ao resgate da cidadania e com a obtenção e ampliação do acesso a bens e serviços, esses atores influenciaram as decisões e o processo de implementação das políticas públicas para as DST/HIV/Aids desde o início da epidemia.

Este trabalho tem como objetivos: a) identificar e analisar a rede de apoio social criada no processo de implementação das políticas públicas de DST/HIV/Aids no Estado de São Paulo e as articulações intersetoriais presentes nessas políticas; b) caracterizar as Casas de Apoio em HIV/Aids do Estado de São Paulo segundo tipos de financiamento, modalidades de gestão e níveis de assistência. Com relação ao primeiro objetivo, procurou-se identificar e analisar a articulação intersetorial entre a Secretaria Estadual da Saúde e as demais secretarias estaduais, com organizações da sociedade civil ligadas ao movimento de luta contra a aids e com os organismos internacionais, na formulação e implementação das políticas públicas para as DST/HIV/Aids, bem como as formas de representação das Casas de Apoio.

Inicialmente, serão apresentados os dados epidemiológicos da aids no Brasil e, em seguida, a contextualização social e política das respostas governamentais e comunitárias, a interface entre as ações públicas e privadas e os principais aspectos 
da política nacional e da política do Estado de São Paulo para as DST/Aids, no período de 1996 a 2003.

Num segundo momento, será apresentada a análise dos dados qualitativos e quantitativos da pesquisa, que compreende a análise das entrevistas realizadas com informantes-chave, que possibilitaram o estudo dos aspectos de gestão, e as informações sobre as Casas de Apoio em HIV/Aids do Estado de São Paulo, como a sua distribuição geográfica, organização jurídico-administrativa, estrutura física, fontes de recursos, população atendida, atividades assistenciais e capacidade de atendimento. 


\section{QUADRO EPIDEMIOLÓGICO DA AIDS NO BRASIL}

A Organização Mundial de Saúde (OMS, 2006) estimou que, em 2002, 42 milhões de pessoas estariam vivendo com o HIV/Aids no mundo, sendo 5 milhões de novos infectados naquele mesmo ano. Também naquele ano, segundo o Ministério da Saúde, teria havido 3,1 milhões de mortes por HIV/Aids.

As mesmas estimativas apontam um número de 1,5 milhão de adultos e crianças vivendo com o HIV/Aids apenas na América Latina, sendo 150.000 casos de novos infectados.

Dados do Ministério da Saúde informam que, entre os anos de 1980 e 2003, foram notificados no Brasil 310.310 casos de Aids. A Região Sudeste concentrava $68,7 \%$ (213.079) desses casos, a Região Sul 16,10\%, o Nordeste 8,65\%, o CentroOeste $4,5 \%$ e o Norte, 2,1\% (BRASIL, 2004).

Tomando-se como base o ano de 2002 - haja vista o entendimento de que os dados apresentados de 2003 estão subnotificados em decorrência das dificuldades e atrasos no Sistema de Informação de Agravos de Notificação (SINAN) - observase uma redução na taxa de incidência de casos novos em relação ao ano anterior, em todas as Regiões do País, passando de 14,8 para 13,5 por 100.000 habitantes, entre 2001 e o ano subseqüente. Chamam a atenção apenas os Estados de Rondônia, Acre e Pernambuco, os quais apresentam um aumento de incidência da doença, diversamente do que ocorreu nos demais Estados.

Em relação aos municípios, destacam-se São Paulo e Rio de Janeiro, com maior registro de casos de aids em número absoluto, responsáveis por $29 \%$ dos casos do País entre 1980 a 2003. No entanto, verifica-se uma redução tanto no 
número de casos quanto na taxa de incidência nesses municípios, de 1998 até 2002.

Do total de casos notificados no mesmo período, 71,1\% (220.783) são do sexo masculino, o que estabelece uma relação gênero de 2,5 casos em homens para cada caso em mulheres. Essa razão se apresenta numa tendência decrescente, mantendo-se no ano de 2002 em 1,7.

Em ambos os sexos, a faixa etária mais atingida é aquela entre 20 e 49 anos, responsável por $86,5 \%$ do número total de casos diagnosticados.

Com relação à categoria de exposição no mesmo período, verifica-se que $63,8 \%$ (197.902) tiveram exposição sexual e 65\% destes se encontram na subcategoria heterossexual. Confirma-se, ainda, que 20,3\% (63.000) tiveram exposição sangüínea com maior prevalência na subcategoria de UDI (93,8\%) e 2,9\% (8.900) com exposição perinatal.

Pode-se observar uma mudança no perfil da epidemia, no que se refere à categoria de exposição sexual, visto que se verifica redução progressiva na incidência de casos na subcategoria homo/bissexual concomitantemente ao aumento da incidência entre os heterossexuais.

Quanto à exposição sangüínea, também se confirma uma redução na incidência de casos, provavelmente decorrente de um maior controle do sangue e hemoderivados oferecidos nos hemocentros e da redução no número de casos na subcategoria de UDI, a partir de 1997.

Verifica-se que, em relação ao grau de escolaridade, a população mais atingida possui quatro a sete anos de estudo, o que representa $25 \%$ do total de casos notificados. Ao longo da série histórica, observa-se um aumento nos casos nessa faixa, ocorrendo o inverso naqueles com maior grau de escolaridade. 
Torna-se relevante observar um percentual representativo de casos com categoria de exposição e grau de escolaridade ignorado, o que dificulta a análise dos dados. No entanto, percebe-se uma tendência de feminilização e pauperização da epidemia.

Segundo informações do Sistema de Informação de Mortalidade (SIM), no período de 1983 a 2002, foram notificados 149.723 óbitos por aids, observando-se uma tendência de estabilização a partir de 1998, mantendo uma incidência de 6,3/100.000 habitantes nos últimos três anos. Acredita-se que essa tendência seja uma conseqüência da garantia de acesso das pessoas vivendo com aids ao tratamento com anti-retroviral de alta eficácia a partir de 1996.

Dentre as políticas de assistência do Programa Nacional de DST e Aids, o acesso universal aos anti-retrovirais tem garantido o tratamento para $100 \%$ das pessoas com aids, o que totalizou, em 2002, 120.000 pacientes. Essa política possibilitou redução de 50\% no índice de mortes por aids no País, tendo sido evitados 90.000 óbitos entre 1996 e 2002. A terapia combinada de anti-retrovirais (ARV) também possibilitou uma redução no número médio de internações por paciente, saindo de uma taxa média 1,65 em 1996 para 0,28 em 2001. Como conseqüência, registra-se uma sobrevida das pessoas vivendo com aids 12 vezes maior, passando de uma média de cinco meses para a média de 58 meses (PROGRAMA NACIONAL DE DST E AIDS 2002, 2002). 


\section{AS POLÍTICAS DE SAÚDE PARA AS DST/AIDS NO BRASIL}

Um aspecto importante no processo de construção da política nacional de combate à aids é o fato de que, desde o surgimento dos primeiros casos de aids, a demanda por atendimento sempre esteve caracterizada como uma questão do setor saúde, não apenas para responder às questões de assistência e prevenção, como também para as ações programáticas para a aids, que envolvem questões legais, culturais e sociais. "É como se o conjunto do Estado tivesse caracterizado a AIDS como um problema essencialmente de saúde e designado o Ministério e Secretarias de Saúde para responder em seu nome" (TEIXEIRA, 1997, p. 47).

Foi também a partir do setor saúde que o Estado de São Paulo, local das primeiras respostas do governo e da sociedade civil em relação à aids, desenvolveu estratégias e construiu os referenciais éticos e políticos que não apenas foram reproduzidos em outros Estados, como passaram a fazer parte do discurso oficial brasileiro no processo de instituição do Programa Nacional de Aids. Um breve histórico do PE DST/AIDS de São Paulo é encontrado no próximo tópico.

O Programa Nacional de AIDS foi criado em maio de 1985, por meio da Portaria n. ํ236, de 02-05-1985, período no qual o Ministério da Saúde estabeleceu as primeiras diretrizes e normas para o enfrentamento da epidemia (BASSO, 2002). Essa iniciativa se deu depois de já existirem mais de dez Estados com programas organizados. Numa reunião com representantes dos Estados, das ONGs e da imprensa, realizada em agosto do mesmo ano, o Ministério da Saúde apresentou as estratégias a serem adotadas, entre elas a designação da Divisão de Dermatologia Sanitária (DHDS) São Paulo - como Centro de Referência Nacional. 
Com uma atuação incipiente nesse ano, foi somente a partir de 1986 que o Programa Nacional de Aids se consolidou, passando a ter um panorama nacional da epidemia propiciado pelas articulações macrorregionais, a disseminação das ações nos Estados e pela participação das ONGs. O Ministério da Saúde incorporou a política de defesa dos direitos dos afetados, reivindicação dos setores da sociedade civil.

Entre 1986 e 1988, foram feitas tentativas de inclusão de outros setores institucionais na solução do problema da aids, como o Conselho Federal de Medicina, a Ordem dos Advogados do Brasil, os Ministérios do Trabalho, da Justiça e da Educação, universidades e ONGs que integraram diferentes composições da Comissão Nacional de SIDA $^{2}$. Registra-se que essas tentativas não lograram avanços significativos (TEIXEIRA, 1997).

A partir de 1987, a articulação com o Instituto Nacional de Assistência Médica da Previdência Social (INAMPS) resultou no controle nacional da infecção pelo HIV nas atividades hemoterápicas. Ainda em 1997, o Programa Nacional de Aids elaborou um documento com o plano de atividades para o período de 1988 a 1992. Nesse documento, predominam os discursos técnico e pragmático das ações. Esse processo de consolidação do PN-DST/AIDS é acompanhado por ações centralizadas, nas quais os programas estaduais deixam de ser os interlocutores e passam a ser executores das políticas elaboradas e coordenadas no âmbito federal. Essa centralização fez com que iniciativas pioneiras em outros Estados, e principalmente as originadas no Centro de Referência e Treinamento de Aids do Estado de São Paulo, no âmbito das ações de prevenção e controle do HIV/Aids,

\footnotetext{
${ }^{2}$ SIDA - Síndrome da Imunodeficiência Adquirida.
} 
ficassem pulverizadas, quando poderiam ter sido articuladas pelo Programa Nacional (TEIXEIRA, 1997).

Basso (2002) relatou que nos anos 90/91, no início do governo Collor, ocorreu uma desestruturação nas ações do PN-DST/AIDS, que comprometeu a vigilância epidemiológica e fragilizou a articulação com Estados, ONGs e outras instituições. O governo assumiu um discurso discriminatório e de exclusão dos soropositivos, sob alegação de que as ações governamentais estavam voltadas para os não infectados. Por outro lado, o governo tomou a decisão de adquirir e distribuir gratuitamente os medicamentos para os pacientes de aids de todo o País. Essa medida, contrariando o discurso anterior, reconhecia o direito das pessoas afetadas a terem acesso ao anti-retroviral.

Em 1992, o PN-DST/AIDS voltou a se organizar, retomando a articulação com estados, ONGs e organismos internacionais. Esse período foi marcado pelo processo de elaboração e negociação de projeto de parceria com o Banco Mundial.

O Ministério da Saúde, em 1994, assinou o primeiro acordo de empréstimo com o Banco Internacional para a Reconstrução e Desenvolvimento (BIRD) - o chamado AIDS I - que previa o recebimento de recursos num valor total de 250 milhões de dólares, com uma contrapartida nacional de 90 milhões de dólares e período de vigência até 1998. O projeto AIDS I tinha como meta geral a redução da incidência e da transmissão do HIV e das DST e previa o desenvolvimento das ações no âmbito do Sistema Único de Saúde, com o fortalecimento das instituições, públicas e particulares, responsáveis pelo controle da aids. A política de aplicação e gerenciamento desses recursos deu-se de forma descentralizada. Na esfera pública, foram feitos convênios com 26 Estados, o Distrito Federal e 43 municípios. Também 
foram financiadas ações de organizações da sociedade civil, universidades, entidades de classe e outras.

Em 1998, foi efetuado o acordo de empréstimo do Projeto AIDS II com vigência até 2002. Com um volume total de recursos de US $\$ 300.000 .000$, o AIDS II exigiu uma contrapartida de US\$ 135.000 .000 de recursos nacionais para a liberação de US $\$ 165.000 .000$ de recursos externos. Os recursos foram aplicados de forma similar aos do AIDS I, atendendo aos mesmos objetivos de redução da morbimortalidade decorrente das DST e da infecção pelo HIV, de promoção e adoção de práticas seguras relacionadas com a transmissão sexual e parenteral do HIV, de garantia da qualidade de vida do sistema diagnóstico de laboratório das DST e da infecção pelo HIV e de fortalecimento e ampliação da participação das instituições públicas e privadas que prestam assistência em DST e aids. Além de dar prosseguimento às ações já realizadas, os recursos do projeto AIDS II foram utilizados no aprimoramento dos processos de gerência e na ampliação da incorporação tecnológica e da área de pesquisas.

O aporte de recursos do Banco Mundial definiu uma nova forma de atuação do Programa Nacional de DST e Aids. Como assinala Teixeira (1997, p. 64),

\footnotetext{
Concluídas as negociações, a atuação do programa e suas relações com os governos estaduais e municipais, universidades e ONGs passam a se concentrar nas questões relativas à execução do Projeto do Banco Mundial. $O$ volume de recursos envolvido, as novas possibilidades de trabalho criadas e o conjunto de normas introduzidas pelo projeto provocaram mudanças significativas na organização do trabalho de todas as instituições nacionais envolvidas com a prevenção e controle da AIDS.
}

Reconhecida como uma característica do Programa Nacional de DST e Aids, desde as primeiras respostas governamentais, a parceria com a sociedade civil se fortaleceu e se ampliou com o financiamento de projetos de prevenção e assistência 
aos infectados e com sua participação nos espaços institucionais de formulação, planejamento, acompanhamento e avaliação das políticas de DST/Aids.

Após todos esses anos de experiência, foi possível constatar que as questões relativas ao enfrentamento da aids têm recortes sociais, culturais e legais que apontam a necessidade de uma articulação intersetorial nos diversos níveis governamentais. As respostas às questões da aids se tornam ainda mais complexas à medida que as camadas mais pobres da população começam a ser afetadas pela epidemia, exigindo a atenção de outros setores das políticas públicas. No entanto, apesar de suas implicações nas demais áreas das políticas públicas, tem prevalecido a abordagem da epidemia como uma questão de saúde, aspecto que será problematizado neste trabalho. 


\section{CONSIDERAÇÕES SOBRE O CONTEXTO SOCIAL E POLÍTICO DA AIDS E AS RESPOSTAS COMUNITÁRIAS}

\subsection{POLÍTICAS SOCIAIS NO ESTADO NEOLIBERAL}

As propostas e estratégias de reforma do Estado, disseminadas nos países capitalistas centrais, na década de 70 , como resposta à crise dos Sistemas de BemEstar Social, foram pautadas no ideário neoliberal e tinham como principal diretriz a racionalidade econômica. Em linhas gerais, a reforma indicava a redução do tamanho do Estado, a diminuição da intromissão dos governos nos mercados e a expansão seletiva do Estado em algumas áreas, devendo atuar apenas como regulador. Além disso, a concepção negativa da atuação do Estado apontava a privatização, a descentralização e a introdução de mecanismos de mercado no setor público como saída para a ineficiência das políticas sociais.

Nos países capitalistas periféricos, na América Latina, onde o Estado de Bemde Estar Social não chegou a conquistar os direitos sociais obtidos nos países capitalistas centrais, as políticas de ajuste econômico neoliberais produziram uma exclusão social ainda maior. Esse processo deu-se de forma diferenciada em cada país, variando de acordo com a natureza, a extensão e a intensidade das medidas de ajuste adotadas pelos governos (SOARES, 1999).

No início dos anos 90, verificou-se um aumento no nível de empobrecimento da população dos países latino-americanos, mais notadamente naqueles de maior tamanho econômico e populacional, como o Brasil. Embora tenha havido um recrudescimento da pobreza absoluta no Brasil nesse mesmo período, num país de tamanha extensão geográfica, a parcela de sua população que vive em situação de 
exclusão social assume grandes proporções, sendo os benefícios sociais fundamentais para essa massa de pessoas carentes, para quem falta, muitas vezes, as condições mínimas de sobrevivência.

Ainda como resultado das políticas de ajuste econômico, ao processo de agravamento da pobreza soma-se a recessão no âmbito das políticas sociais, por meio da redução do acesso aos serviços, o que contribui para a deterioração crescente das condições de vida da população empobrecida. Ou seja, a falta de investimentos para ampliação das políticas, a redução de serviços e benefícios sociais ofertados pelo governo e o aumento da população em situação de pobreza geram o aumento da exclusão entre os segmentos populacionais que mais necessitam dos benefícios sociais.

Para superação da crise econômica, as reformas do Estado preconizam a contenção de custos e o controle de gastos em todos os setores estatais. Essas mudanças exigem que, no âmbito das políticas sociais, sejam priorizados os programas assistenciais básicos e segmentos populacionais mais pobres. Como assinala Viana (1998, p. 27), "[...] sem ter constituído políticas sociais vigorosas, o Brasil já precisa implementar modificações substantivas nas formas de funcionamento, operação e gestão dessas políticas".

Ao mesmo tempo, as agências financiadoras - Organização Mundial da Saúde (OMS), Organização Pan-Americana de Saúde (OPAS), Banco Mundial exercem forte influência no processo de reforma nos países latino-americanos. Apresentando argumentos, como os da ineficiência das instituições públicas, existência de monopólios, gigantismo da máquina estatal e iniqüidade na oferta de bens e serviços, as agências financiadoras, em especial o Banco Mundial, no setor saúde, influenciam os governos no sentido de implantar políticas sociais compatíveis 
com a lógica da reforma neoliberal. As questões de saúde passam a ser abordadas como mais uma oportunidade de mercado, de acumulação de capital, originando novas relações de poder dentro do setor saúde com a emergência de atores fortes como os dos serviços privados. As diretrizes da reforma conduzem as políticas públicas de saúde para as seguintes ações: focalização da ação governamental na população mais carente, opondo-se ao universalismo; priorização de gastos públicos para ações de impacto coletivo ou de alta eficácia em função dos custos; separação entre financiamento e prestação de serviços; introdução de mecanismos de mercado entre prestadores públicos e privados; ênfase na efetividade e incentivo a novas formas de custeio (SOARES, 1999).

No Brasil, a reforma no sistema de saúde deu-se no contexto da Assembléia Nacional Constituinte, quando a saúde ganha o estatuto de seguridade social na Constituição de 1988. Na contramão das propostas neoliberalistas, promove-se um sistema de saúde único, público e universal, descentralizado e com a participação da sociedade no controle da implementação das ações. É importante considerar que a viabilidade prática da reforma depende, entre outros fatores, do contexto político em que ela é implementada. Então, apesar de ter suas bases garantidas na Constituição, o SUS não se tornou uma política de Estado, estando submetido aos interesses de governos momentâneos e, portanto, ainda enfrenta problemas na sua completa efetivação, como a força política dos representantes dos serviços privados, cada vez mais maduros e fortes na defesa de seus interesses, e as fontes de financiamento, que o tornam vulnerável em frente aos revezes da política econômica nacional. O financiamento permanece pautado pelo modelo previdenciário, modelo este fundamentado na economia formal e nos salários e que foi organizado para 
atender apenas a determinados segmentos da população e não às ações de caráter universal do atual sistema de saúde.

Nos anos 90, período marcado por constantes disputas por recursos, a política de descentralização no setor saúde, pensada como estratégia para produzir maior eficiência na oferta de serviços, assume: um caráter tecnocrático relativo à operacionalização do sistema; a relação entre gestores; os critérios de transferência de recursos federais para Estados e municípios, enfatizando uma racionalidade técnica que esvazia a dimensão política da descentralização. As organizações sociais são apontadas como uma estratégia importante no processo de descentralização e desconcentração previsto no modelo de reforma neoliberal, por sua autonomia administrativa e por disporem de mecanismos gerenciais característicos da esfera do mercado, o que as torna uma alternativa importante para a participação de outros atores da sociedade civil na prestação de serviços sociais e científicos, possibilitando a redução das ações estatais.

Com a estratégia de focalização dos serviços no atendimento às populações mais pobres, o que amplia o contingente de excluídos, o fomento, por parte do governo às atividades das organizações não-governamentais, por meio de financiamentos de projetos pontuais, assume a roupagem de um ideário político democrático, que possibilita ampla participação dos usuários dos serviços nos processos de decisão e implementação das políticas de saúde para as DST/Aids. No entanto, a experiência de outros países que adotaram o modelo de reforma neoliberal aponta:

[...] o esvaziamento do setor público, e o conseqüente desmantelamento de seus serviços sociais, fez-se acompanhar por um retrocesso histórico, qual seja, o retorno à família e aos órgãos da sociedade civil sem fins lucrativos, como agentes de bem-estar social. Isto vem implicando uma renúncia explícita do Estado em assumir sua responsabilidade na prestação de 
serviços sociais (sobretudo saúde e educação) em bases universais. A opção pelos mecanismos de auto-ajuda se dá mais pela ausência de impacto financeiro sobre o setor público do que pelos méritos organizativoparticipativos da sociedade (SOARES, 1999, p. 346).

As cristalizações produzidas no seio das políticas de DST/Aids, parecem impelir os atores governamentais e não-governamentais envolvidos na formulação e implementação das políticas de DST/Aids à repetição do discurso de que a parceria com as organizações da sociedade civil e o controle social são os principais responsáveis pelo sucesso do Programa Nacional de DST e Aids. Sem levantar dúvidas sobre esse fato, vale questionar a sustentabilidade política dessa articulação e a representatividade dos diversos atores, tarefa proposta para este trabalho no capítulo sobre as políticas de DST/Aids no Estado de São Paulo.

\subsubsection{A resposta comunitária}

A epidemia se desenvolveu em meio aos processos de ajustes estruturais em vários países, inclusive no Brasil, e durante uma crise na Saúde Pública e nas demais políticas sociais, e as respostas sociais ao HIV/Aids precisam ser entendidas dentro desse contexto social, político e ideológico presente no surgimento e no decorrer da epidemia, nas diversas sociedades afetadas. Esses aspectos determinaram condições de vulnerabilidade da população, forma de alocação de recursos, investimentos em pesquisa, medicamentos, qualidade da atenção à saúde, entre outros (ALTMAN, 1995).

Atualmente, é inegável o papel fundamental desempenhado pela sociedade organizada, das mais diversas formas, no enfrentamento da epidemia de aids no Brasil e no mundo. Desde o início da epidemia de aids, quando ainda não havia uma 
resposta governamental efetiva, a mobilização comunitária se sobrepôs à inércia governamental, chamando a atenção da população em geral para a gravidade do problema (DANIEL; PARKER, 1991; PARKER, 1994). A despeito do importante papel desempenhado pelas organizações não-governamentais, não se pode esquecer de que as ações de prevenção e assistência em DST/Aids fazem parte de um conjunto de ações estratégicas que compõem as políticas de saúde do governo e, como tal, encontram-se inseridas no modelo de reforma adotado pelo Estado. Como Dennis Altman sugere, para alguns, o setor voluntário é um complemento das ações governamentais e, para outro grupo, pode ser um espaço de transformação das estruturas sociais por meio da transformação da consciência política (ALTMAN, 1995, p. 37).

Em seu surgimento, as organizações comunitárias formadas para enfrentamento da aids sofreram forte influência do movimento ocorrido nos Estados Unidos. O histórico do surgimento das diversas respostas comunitárias em todo o mundo, bem como a influência do movimento gay americano, o trabalho dos voluntários, das igrejas e das mais diversas organizações de base comunitária foram documentados por Altman (1995), oferecendo uma visão global das contribuições que essas instituições e os movimentos de ativistas têm oferecido em todo o mundo.

Entre as décadas de 70 e 80 , os movimentos sociais desenvolviam suas atividades em oposição ao Estado, particularmente nos contextos ditatoriais. Os movimentos sociais dos anos 70 se desenvolveram à margem dos recursos locais, utilizando-se do apoio das agências de cooperação internacionais, de caráter não governamental, e que precisavam de parceiros locais para executar seus projetos, fora dos governos e da iniciativa privada. 
A atividade associativa ganha impulso nos anos 80 e as organizações nãogovernamentais surgiram vinculadas aos movimentos sociais desses anos, como uma nova forma institucional, introduzindo o neologismo ONGs, hoje reconhecido em diversas línguas (FERNANDES, 1994; MONTAÑA, 2002). O termo Organização NãoGovernamental não está legalmente definido, mas segundo Landim (2001, p. 1):

[...] uma categoria que vem sendo socialmente construída e usada para designar um conjunto de entidades com características peculiares, reconhecidas pelos seus agentes, pelo senso comum ou pela opinião pública.

Na América Latina, o surgimento das ONGs parece ser um dos sintomas mais claros do surgimento de um terceiro setor, resumindo o que se afirma serem instituições privadas com funções públicas. Essas organizações são freqüentemente designadas como "não lucrativas" e "não governamentais". No entanto, essas características, por si sós, não colocam essas instituições fora da influência do Estado e do mercado e das questões sociais (FERNANDES, 1994, p. 21, 24). O conceito de terceiro setor é entendido internacionalmente como um conjunto de organizações e iniciativas privadas que visam à produção de bens e serviços públicos, que não geram lucros e atendem a finalidades públicas ou coletivas (FERNANDES, 1994; FALCONER; VILELA, 2001).

A partir do final dos anos 80 , com o advento da Constituição de 88 , os movimentos sociais mudam a estratégia de enfrentamento e pressão contra 0 Estado e incorporam um comportamento de articulação, de parceria com o Estado. Há indícios de que, com a mudança nas prioridades de financiamento dos apoiadores internacionais, as organizações tiveram que recorrer a fontes de financiamentos nacionais. Dessa forma, as relações dos movimentos sociais com o Estado passam cada vez mais fortemente a serem intermediadas pelas ONGs e o 
repasse de recursos públicos para essas instâncias privadas vem acompanhado de uma utilidade política governamental que tem, no fortalecimento da solidariedade e na participação cidadã, o seu argumento central.

Como Montaña (2002, p. 57-58) bem observa, o caráter não-governamental das ONGs e sua suposta autonomia merecem reflexão, uma vez que muitas dessas organizações estabelecem parcerias com o Estado, nos níveis municipal, estadual e ou federal, para desempenhar funções a ele atribuídas. Ao desenvolver suas atividades com financiamentos governamentais, fonte importante de recursos dessas organizações, as ONGs, acabam se integrando a uma determinada política de governo e sua autonomia na gestão ideológica parece ficar condicionada à abrangência e prioridades da política governamental vigente. Ao mesmo tempo, embora essas organizações não tenham fins lucrativos, pode-se falar em lucros indiretos quando parte dos custos operacionais dessas organizações e, por vezes, o custeio de salários para pessoas que executam as ações são financiados com recursos governamentais. Vale aqui uma distinção entre governo e Estado, assinalado que, embora as parcerias se estabeleçam com o Estado, as propostas seguem as diretrizes do perfil ideológico dos Governos Federal, Estadual ou Municipal com o qual a parceria se estabeleceu.

Partindo das considerações acima, ao longo deste trabalho, apresentaremos como tem sido o modo de inserção dos representantes da sociedade civil no processo de decisão e implementação das políticas para as DST/HIV/Aids no Estado de São Paulo. 


\subsection{AÇÃO INTERSETORIAL: ESTADO E ONGS}

A gestão das necessidades e demandas dos cidadãos tem se dado, no âmbito das políticas sociais, ainda de forma muito fragmentada e desarticulada. A implantação de uma estratégia de intersetorialidade no campo de ação dessas políticas pode possibilitar a ampliação da inclusão social e a integralidade das ações. A intersetorialidade em saúde tem sido definida "[...] como a articulação entre os saberes e experiências no planejamento, realização e avaliação de ações para alcançar efeitos sinérgicos em situações complexas" (JUNQUEIRA; INOJOSA, 1997 apud FERREIRA; SILVA, 2005, p. 103). Ainda segundo Ferreira e Silva (2005), desde 1961, a intersetorialidade em saúde aparece nos principais planos e programas de organismos internacionais, como a OMS, em diferentes eventos em todo o mundo e, no Brasil, a proposta existe desde a década de 70 e já na $\mathrm{VI}$ Conferência Nacional de Saúde surge como objetivo da Política Nacional.

A gama de problemas psicossociais que, em geral, acompanha o diagnóstico do HIV/Aids, em especial em pessoas empobrecidas e já marcadas pela exclusão social, desafia com todas as suas complexidades a capacidade de resolução exclusiva por parte dos profissionais de saúde e das ações governamentais. Muitas vezes, os problemas sociais que se apresentam exigem soluções emergenciais, possibilitando que a parceria com o Estado ganhe cada vez mais adeptos na busca de soluções para a sobrevivência à epidemia e para proporcionar mais qualidade de vida para as pessoas por ela afetadas.

Viana (1998) afirmou que as mudanças nas relações sociais e no modo de produção capitalista, que resultaram, entre outras, na instabilidade no emprego e em ganhos insuficientes para custeio das necessidades mínimas de sobrevivência, 
ocasionaram também mudanças na estrutura familiar nuclear, exigindo que não apenas o homem seja o provedor da família, mas que também mulheres e, não raro as crianças e jovens, busquem alguma forma de obtenção de renda para minimizar os danos da pobreza. Os novos riscos sociais exigem respostas que nem sempre se inscrevem nos conteúdos e programas tradicionais das políticas sociais. Dessa forma, sublinha Viana (1998, p. 25), "[...] entra na ordem do dia a intersetorialidade das políticas, onde as ações sociais são compostas por diferentes tipos de intervenção pertencentes a diferentes tipos de políticas”.

Segundo Junqueira (2004, apud OLIVEIRA; JUNQUEIRA, 2003, p. 26), essas organizações do terceiro setor "[...] são espaços institucionais que não se restringem apenas a um setor, são organizações que materializam a realidade intersetorial. São espaços que desenvolvem a cidadania”.

A parceria do Estado com as ONGs, longe de substituir as organizações públicas, constitui-se numa alternativa de descentralização das políticas sociais e imprime uma visão integral em frente aos problemas sociais. A proposta é que as políticas sociais se tornem mais ágeis ao serem executadas por parceiros privados voltados para os interesses coletivos e, ao mesmo tempo, garantam que o Estado assuma sua responsabilidade relativa aos direitos sociais. A inovação nesse processo se dá a partir de novas respostas criadas por esses parceiros, que compõem uma grande rede social, abordando os problemas locais de forma integrada, a partir de objetivos e demandas coletivas.

Certamente a parceria Estado-sociedade ou as intervenções da sociedade civil, isoladas, não oferecem soluções universais para todos os problemas sociais que perpassam a epidemia de aids no Brasil, mas a ação das ONGs pode contribuir para a redefinição das políticas a fim de imprimir mais eficiência e efetividade à 
ação estatal no campo da aids. A intersetorialidade possibilita maior eqüidade na assistência e pressupõe uma abordagem dos problemas sociais no território onde eles ocorrem, melhorando a capacidade de respostas mais próxima da realidade. Nesse sentido, as ONGs contribuem de forma especial, pois possuem extenso conhecimento sobre a realidade com a qual mantêm constante interação, além do seu comprometimento com o bem coletivo, acima dos interesses individuais.

A visão integrada das políticas sociais ainda não é uma prática comum dos gestores e

[...] a ação intersetorial é um processo de aprendizagem e determinação dos sujeitos [...], constitui uma concepção que deve informar uma nova maneira de planejar, executar e controlar a prestação de serviços, para garantir um acesso igual aos desiguais. Isso significa alterar toda forma de articulação dos diversos segmentos da organização governamental e dos seus interesses (JUNQUEIRA, 2004, p. 27).

As pressões exercidas pelos grupos organizados impõem aos governos um olhar não sobre as carências dos cidadãos, mas sim sobre o que são seus direitos sociais, como o de acesso à saúde, habitação, lazer e outras condições necessárias para a promoção de qualidade de vida. 


\section{POLÍTICAS EM DST/AIDS NO ESTADO DE SÃO PAULO}

Em 1983, registrando o maior número de casos de aids do País, o Estado de São Paulo criou o primeiro Programa de Aids brasileiro, antecipando até mesmo o surgimento do Programa Nacional. Com a mobilização dos movimentos sociais organizados, foram formuladas as primeiras respostas à epidemia, ancoradas, desde seu início, pelas ações em parceria, e que tinham como objetivo a vigilância epidemiológica, a redução do pânico e da discriminação na sociedade por meio da disseminação de informações sobre a doença, a garantia de atendimento aos doentes e a orientação aos profissionais de saúde (BASSO, 2002).

Ao contrário da forma tradicional de criação e implementação dos programas de saúde pública, o Programa de Aids nasceu da iniciativa das pessoas afetadas pelo agravo e não dos parâmetros que enquadram um agravo como problema de saúde pública ${ }^{3}$ (BASSO, 2002).

Um histórico minucioso do surgimento do Programa Estadual de Aids de São Paulo está descrito na dissertação de mestrado de Guerra (1993), que enfoca o perfil das políticas de saúde da época e analisa como a aids se inseriu naquele contexto. Neste trabalho, no entanto, será feito um curto relato desse histórico, a fim de contextualizar as informações que, posteriormente, comporão a análise do processo de formulação das políticas de DST/Aids no Estado de São Paulo.

Em 1983, um grupo de homossexuais, à época identificados como grupo de risco para o HIV/Aids, uma médica e um antropólogo solicitaram à Secretaria de

3 Basso (2002) faz um breve histórico do surgimento do Programa Nacional de DST/Aids e do Programa Estadual de DST/Aids de São Paulo, destacando o processo de evolução das políticas de DST/Aids que culminaram com sua inserção no SUS. A autora enfoca aspectos gerenciais do Programa Nacional de DST e Aids e aborda os principais resultados nas áreas de prevenção, assistência, DST, a repercussão do uso de ARV e a política farmacêutica. 
Estado da Saúde de São Paulo (SESSP) providências para o atendimento dos possíveis casos que surgiriam em São Paulo. A demanda foi encaminhada para o Serviço de Epidemiologia e Estatística da Coordenadoria de Saúde da Comunidade, que designou uma equipe técnica para tratar do assunto. Desde as primeiras reuniões da equipe técnica, a população afetada fez-se presente, uma vez que líderes da comunidade homossexual demonstram ter mais conhecimento sobre a doença do que os profissionais de saúde e, portanto, detinham uma visão mais ampla sobre a gravidade do problema. No entanto, para além das preocupações individuais, os técnicos da saúde consideraram que a questão se tratava de um problema de saúde pública devendo, portanto, ser controlado pelo Estado (GUERRA, 1993).

Inicialmente, o PE DST/AIDS ficou sediado na Divisão de Hansenologia e Dermatologia Sanitária (DHDS), órgão do Instituto de Saúde da SESSP, com o objetivo de que os investimentos nessas ações fossem mantidos dentro da própria instituição. Foram definidos alguns serviços de referência hospitalar como o Instituto de Infectologia Emílio Ribas; o Hospital das Clínicas; o Hospital dos Servidores Públicos Estaduais; o Instituto Adolfo Lutz, como referência laboratorial; o serviço de atendimento ambulatorial da seção de Elucidação Diagnóstica da DHDS; além de um serviço de Disque-Aids para informações por telefone. A divulgação dessa estrutura pela imprensa gerou uma grande demanda de solicitações de informações e assistência médica por parte da população e busca de orientação técnica para profissionais de saúde.

Basso (2002) salienta que essa primeira estrutura de serviço foi a base do que, posteriormente, se tornou o Centro de Referência e Treinamento em Aids (CRT-A), instituição vinculada ao gabinete do Secretário de Saúde. O modelo de 
organização de serviços apoiados na dermatologia sanitária, responsável pelo atendimento às DSTs, foi utilizado por outros Estados e pelo Ministério da Saúde.

Em 1985, com o crescimento do número de casos, sem financiamento do Ministério da Saúde ou do INAMPS e sem recursos financeiros disponíveis na SESSP, o Programa de Aids enfrentava muitas dificuldades, sendo a falta de leitos uma das mais importantes. A gravidade da falta de leitos resultou na criação de um hospital específico para paciente com aids, o Hospital Emílio Ribas 2, instalado num prédio alugado pela SESSP.

Vale destacar que o problema da falta de leitos mantém estreita relação com o tema deste trabalho, pois é no âmbito dessa questão que surge a primeira Casa de Apoio em HIV/Aids no Brasil.

Em 1987, com a eleição do governador estadual, o então novo secretário de Estado da Saúde, por meio de uma Resolução, transferiu a Coordenação do Programa Estadual de Aids, e todas as atividades e recursos relacionados com o controle da Aids, para o Hospital Emílio Ribas. O Programa de Aids, que sempre manteve uma relação direta com o Gabinete do Secretário Estadual da Saúde, contava agora com respaldo político e, nesse período, o trabalho caracterizou-se por uma maior articulação e integração entre os diversos profissionais que trabalhavam com aids, dentro e fora da SESSP.

No início de 1988, com a permanente falta de leitos hospitalares, foi criada uma Central de Vagas que, juntamente com uma Resolução do secretário Estadual, ampliava o número de leitos hospitalares na rede pública estadual, além de estabelecer um Hospital-Dia. A concepção do Hospital-Dia foi modificada e ampliada para atender a outras necessidades, como a capacitação de pessoal, a integração com o serviço ambulatorial, as ações educativas e de vigilância epidemiológica. 
Assim, em 1988, com total apoio da SESSP, foi criado o CRT-A, com o objetivo de ser a referência técnica para profissionais de saúde, mas que oferecia também alternativas assistenciais, como o Hospital-Dia e a Assistência Domiciliar Terapêutica. Em 1993, após incorporar as ações do Programa de Doenças Sexualmente Transmissíveis, transforma-se no Centro de Referência e Treinamento em DST/AIDS (CRT-DST/AIDS).

O CRT-DST/AIDS foi criado por meio de uma resolução da Comissão Interinstitucional de Saúde do Estado (CIS), que era o órgão deliberativo de maior nível hierárquico do Sistema Unificado e Descentralizado de Saúde (SUDS) à época.

Em 1995, ocorreu a unificação da direção do CRT-DST/AIDS com a Coordenação do Programa Estadual de DST/AIDS. Essa estratégia possibilitou a delimitação mais clara do importante papel da instituição, agora responsável pela implementação, coordenação e supervisão das políticas e estratégias relativas às DST/Aids em todo o Estado, no âmbito da prevenção, assistência e vigilância epidemiológica, além da gerência das ações desenvolvidas em todo o Estado.

Em 1996, o CRT-DST/AIDS passa a ser vinculado à Coordenadoria dos Institutos de Pesquisa, órgão responsável pela definição das políticas de saúde pública da Secretaria de Estado da Saúde de São Paulo, atualmente denominado Coordenadoria de Controle de Doenças. 


\section{AÇÃO INTERSETORIAL NO CAMPO DAS DST/AIDS}

\subsection{A EXPERIÊNCIA DO ESTADO DE SÃO PAULO}

A investigação realizada com atores-chave envolvidos no processo de formulação e implementação das políticas de DST/Aids, no Estado de São Paulo, revelou uma crescente e permanente articulação entre os vários atores do cenário da luta contra o HIV/Aids.

Giana (2005), a representante da CE DST/AIDS, descreveu a existência de um fórum de articulação que se reúne desde 1997, e que é composto por interlocutores da Divisão Nacional de Saúde, Coordenações Municipais de DST/AIDS (dos 144 municípios que recebem recursos de incentivo do Ministério da Saúde), representantes da sociedade civil e de outras áreas das Secretarias de Estado da Saúde, por exemplo, o Instituto Adolfo Lutz. Inicialmente, quando apenas 37 municípios eram contemplados com os recursos oriundos de convênio, as reuniões eram realizadas a cada dois meses. Com a ampliação do número de municípios contemplados, as reuniões passaram a acontecer duas vezes por ano, sendo uma no primeiro semestre e a outra no segundo (Informação verbal). ${ }^{4}$

Apesar de ser um dos principais espaços de discussão das políticas de DST/Aids, esse fórum não está registrado em Diário Oficial e sua legitimidade se dá por meio do compromisso de cada participante com o objetivo do fórum.

Anualmente, é realizada uma reunião com os Estados e municípios da Região Sudeste, chamada Macrorregional Sudeste, da qual participam também os 144

\footnotetext{
${ }^{4}$ Comentário da Coordenadora Adjunta do PE DST/AIDS de São Paulo, Maria Clara Giana, em entrevista concedida à autora desse trabalho,em 2005.
} 
municípios do Estado de São Paulo. Além dessas três reuniões, a CE DST/AIDS adotou uma estratégia de articulação regionalizada que envolveu a realização de reuniões macrorregionais, conhecidas como Macrorregional Grande São Paulo, Macrorregional Campinas, Macrorregional Ribeirão Preto, Macrorregional Litoral e Vales (do Paraíba e do Ribeira) e Macrorregional São José do Rio Preto. ${ }^{5}$ A definição dessas macrorregiões não é oficial, pois a CE DST/AIDS não tem autonomia política para criar regionais específicas para os programas de Aids. Esses encontros também acontecem duas vezes por ano e têm possibilitado discussões importantes com as Direções Regionais de Saúde (DIR) (Informação verbal).

O PE DST/AIDS também mantém uma articulação permanente com a sociedade civil organizada por meio da participação mensal nas reuniões do Fórum de ONGs/Aids do Estado de São Paulo. Esses encontros são um espaço importante para monitoramento e avaliação das ações implementadas ou a serem implementadas. Conforme previsto na lei de repasse do incentivo do Ministério da Saúde, as propostas do Plano de Ações e Metas (PAM) do PE DST/AIDS são previamente discutidas com a sociedade civil organizada, por meio de suas representações, antes de serem submetidas à aprovação do Conselho Estadual de Saúde.

O PAM dispõe de recursos a serem repassados para as organizações da sociedade civil que desenvolvem trabalhos de prevenção e atenção aos portadores do HIV/Aids, por meio do financiamento de projetos.

Para encaminhamento do processo que define os critérios do repasse, como os termos da concorrência pública dos projetos a serem financiados, a CE DST/AIDS criou uma portaria interna do CRT-DST/AIDS instituindo o já atuante

\footnotetext{
${ }^{5}$ A denominação Macrorregional é usada apenas internamente pela equipe de técnicos do CRT. Oficialmente, a nomenclatura utilizada é "Grande Região".
} 
Grupo de Trabalho OG/ONG - GT OG/ONG. Esse grupo constitui-se também num importante espaço de articulação entre Estado e sociedade civil, em especial por seu caráter deliberativo, no que se refere aos recursos destinados à sociedade civil. A Portaria prevê a participação de representantes do Estado (CE DST/AIDS), dos municípios (CM DST/Aids), do Fórum de ONGs/Aids, da Rede Nacional de Pessoas Vivendo com o HIV/Aids (RNP) e Fórum de Gays, Lésbicas, Transgêneros, Travestis e Bissexuais (Fórum GLTTB). É o GT/ONG que define também os componentes do Comitê Seletivo Externo que faz a seleção dos projetos a serem financiados (GIANA, 2005).

Os representantes do governo e sociedade civil concordam que a articulação com as demais Secretarias de Estado ainda é limitada, com participação de alguns setores em eventos e reuniões de forma não sistemática (DUDA, 2005; GIANA, 2005; HENGLES, 2005). ${ }^{6}$ Por parte do CE DST/AIDS encontra-se uma articulação mais permanente com a Secretaria de Estado da Educação e a Secretaria de Assuntos Penitenciários. Essas Secretarias não possuem uma agenda predefinida para os temas, composição e periodicidade das reuniões. A Secretaria de Ação Social não tem tido participação nas discussões. Existe ainda um trabalho que vem sendo desenvolvido em parceria com a FEBEM, mas que, segundo parecer da representante do PE DST/AIDS, precisa ser mais bem articulado. A despeito da informalidade desses grupos de trabalho, o PE DST/AIDS afirma que tem buscado garantir a representatividade dos participantes e o envolvimento de todos os segmentos interessados como DIR, Secretarias Municipais de Saúde e sociedade civil organizada.

\footnotetext{
${ }^{6}$ Depoimento de Rubens Oliveira Duda, presidente do Fórum de ONGs/Aids do Estado de São Paulo, Silvana Hengles, responsável pelo Setor de Articulação com a Sociedade Civil Organizada e Maria Clara Giana, Coordenadora Adjunta do PE DST/AIDS de São Paulo.
} 
A articulação com a Secretaria de Estado da Educação tem contribuído para os avanços na incorporação dos temas de DST/Aids e de outros temas na grade curricular. O papel da CE DST/AIDS é o de fomentar a articulação local, promovendo um maior envolvimento das Secretarias Municipais de Educação e instâncias regionais, uma vez que cabe a essas instituições a execução das ações.

Em relação à Secretaria de Assuntos Penitenciários, o objetivo é buscar garantir a atenção integral à saúde das populações confinadas, no que diz respeito aos portadores da infecção pelo HIV, como viabilizar os exames laboratoriais para os portadores do HIV e também o acesso aos medicamentos ARV e preservativos.

O processo decisório adotado nesses espaços de articulação se dá pelo consenso, a partir das discussões aprofundadas entre os diversos interlocutores até o entendimento do papel e das responsabilidades das várias instâncias governamentais envolvidas e do atendimento das realidades locais.

Apesar de agregar múltiplas organizações governamentais e nãogovernamentais, há muita convergência a respeito da condução das políticas públicas para as DST/Aids. Na década de 80 , questões como a adoção da política de redução de danos para usuários de drogas ou a linguagem dos materiais educativos voltados para a população de homens que fazem sexo com homens eram mais polêmicas, assim como a questão da descentralização das ações propostas às DIR e municípios na década de 90.

Atualmente, com o amadurecimento dos programas estaduais e municipais, há consenso quanto às questões éticas e de direitos humanos dos portadores do HIV/Aids, e os conflitos mais evidentes referem-se às questões ligadas à gestão financeira das ações que ficam sob responsabilidade das Secretarias Estaduais e Municipais de saúde. Nesse aspecto, a questão central é a da descentralização das 
ações versus a descentralização dos custos. Nesse âmbito, os coordenadores dos programas estadual e municipal têm pouca participação na decisão, uma vez que as discussões acontecem na Comissão Bipartite e na Tripartite, com a participação dos secretários estaduais e municipais. Segundo relato da representante do PE DST/AIDS, a questão do financiamento deverá suscitar muitas discussões entre os formuladores das políticas de DST/Aids, pois o Ministério da Saúde tem apontado a necessidade de Estados e municípios destinarem recursos para financiamento dos projetos executados pelas organizações não-governamentais que, hoje, são basicamente financiados pelo Ministério da Saúde, com recursos do Acordo do Banco Mundial e dos Planos de Ação e Metas. A discussão deverá envolver o montante da participação financeira de cada esfera de governo para que a descentralização das decisões e ações esteja alinhada com a descentralização dos recursos financeiros.

No âmbito federal, observa-se o mesmo processo de articulação do nível estadual, como a Comissão de Gestão, que reúne representantes das cinco Regiões do País a cada 40 dias para discutir os principais assuntos da política nacional de DST/Aids. Em situações críticas, como nos casos de desabastecimento de medicamentos e preservativos, o PN-DST/Aids convoca reuniões extraordinárias com os coordenadores estaduais e representantes dos municípios. Um outro importante espaço de articulação do Programa Nacional é a Comissão Nacional de Aids (CNAIDS), composta por diversos setores da sociedade, como representantes da sociedade civil, do Conselho Nacional de Secretários Estaduais de Saúde (CONASS), Conselho Nacional de Secretários Municipais de Saúde (CONASEMS), dos Estados e municípios, universidades, Ministério da Educação. 
De modo geral, alguns dos importantes espaços de formulação e implementação das políticas públicas para as DST/Aids não estão institucionalizados. Mas, de fato, os decisores governamentais têm adotado um sistema de gestão interativa e têm dirigido e absorvido as demandas do conjunto da sociedade afetada por essas políticas, respeitando a história do próprio PNDST/Aids, e mantendo um caráter institucional quando da aprovação das propostas em Conselhos Municipais e Estaduais de Saúde e Comissões Intergestoras Bipartites e Tripartites, de forma que o resultado global parece muito positivo até o momento (GIANA, 2005).

\subsection{A EXPERIÊNCIA DO MUNICÍPIO DE SÃO PAULO}

O processo de formulação das políticas municipais de DST/Aids será descrito a partir da experiência do município de São Paulo, dada a sua magnitude geográfica e populacional e o fato de que nele nasceram as primeiras respostas à epidemia de DST/Aids.

O Programa Municipal de DST/Aids de São Paulo faz parte de uma das 20 áreas temáticas que compõem a Secretaria Municipal de Saúde, como as da Mulher, da Criança, do Adolescente, de Pessoas Portadoras de Deficiências e outras, seguindo o modelo adotado pelo Ministério da Saúde, que atuava com coordenações divididas por áreas temáticas.

A área temática de DST/AIDS possui uma coordenação, que é constituída por um grupo técnico que inclui funcionários da Prefeitura e pessoas contratadas com recursos da UNESCO, denominadas consultores. 
A partir de diretriz da Coordenadoria de Gestão da Saúde, há uma interlocução entre as diversas áreas temáticas, com o objetivo de possibilitar a integralidade na atenção à saúde.

Em relação às demais Secretarias Municipais, as parcerias não obedecem a nenhuma diretriz política ou técnica formal, mas são estabelecidas e incorporadas a partir da necessidade de buscar respostas mais efetivas no combate à aids. Dessa forma, foram realizadas ações em parceria com a Secretaria de Assistência Social, Secretaria de Vigilância Sanitária e Epidemiológica.

Até 2004, a gestão do Programa Municipal era discutida no âmbito da Secretaria Municipal de Saúde, com secretário, coordenadores e com o corpo do Conselho Técnico Gestor, das áreas de prevenção, assistência e articulação com a sociedade civil.

Em novembro de 2002, por ocasião da primeira Conferência Municipal de DST/Aids, iniciou-se um modelo diferenciado de gestão, com a criação da Comissão Municipal de Aids, com representação paritária do governo e da sociedade civil, mais especificamente das organizações de luta contra aids. Esse foi o primeiro avanço no sentido de uma gestão mais participativa, pois as propostas deliberadas durante a Conferência passaram a ser discutidas, referendadas e acompanhadas dentro da Comissão Municipal de AIDS, que tem a paridade de representação. Apesar das discussões entre os diversos atores, o processo decisório ficava centrado na coordenação do Programa Municipal.

Em 2005, foi criado um Grupo Operativo Assessor (GOA), com o objetivo de formular políticas para enfrentamento das DST/Aids dentro de um contexto municipal mais amplo, envolvendo não apenas os serviços de saúde pública, mas também a rede privada. O GOA é composto por quatro representantes dos gerentes dos 
serviços se saúde (de um total 24 serviços de aids), representantes das universidades, da UNESCO, do Conselho Regional de Medicina, da RNP, do Movimento Paulistano de Luta e Articulação contra a Aids, que é um movimento de ONGs/Aids da cidade de São Paulo do Programa Estadual de DST/Aids, além de pessoas técnica e politicamente representativas no contexto de enfrentamento da aids, como o doutor Paulo Roberto Teixeira, que foi coordenador do PN-DST/Aids.

A articulação formal com o Estado se dá nos níveis de gestão do COSEMS e CONASEMS. Em relação ao Programa Estadual de DST/Aids, há um diálogo permanente, com participação de representantes municipais em todos os espaços de formulações de políticas do Programa Estadual.

Do ponto de vista da representante do programa Municipal de DST/Aids de São Paulo, não há conflitos significativos nessa relação.

A articulação com a sociedade civil ganhou mais expressão no Programa Municipal de DST/Aids a partir da criação da Comissão Municipal de Aids, em 2002, por meio da atuação dos Conselhos Gestores dos serviços de saúde que atendem a portadores do HIV/Aids.

Atualmente, os espaços de participação da sociedade civil no processo de formulação das políticas municipais de DST/Aids são Conselhos Gestores, a Comissão Municipal de Aids, a reunião mensal com o Fórum Estadual de ONGs/Aids, a reunião mensal com o MOPAIDS. Essas instâncias estão formalizadas na legislação municipal, que estabelece o funcionamento dos Conselhos Gestores dos Serviços de Saúde, a Comissão Municipal, criada pela Conferência Municipal de Saúde e referendada pelo Conselho Municipal de Saúde. É dado a esses atores acesso à agenda do Ccordenador do PM DST/Aids para discutirem as ações de assistência e prevenção, bem como o acompanhamento das diretrizes do programa. 
Os representantes da ONGs/Aids também estão presentes nas comissões que discutem os projetos de prevenção para as populações mais vulneráveis. São realizadas reuniões abertas, no formato de um grupo de trabalho, para o qual são convidadas todas os ONGs que têm projetos financiados para determinada população além de outros interessados no tema, mesmo que não tenham projetos financiados HENGLES, 2005).

\subsection{A INTERSETORIALIDADE SOB A PERSPECTIVA DAS ONGS/AIDS}

Os esforços dos ativistas ao longo da epidemia de aids culminaram no reconhecimento das instituições públicas da importância do diálogo entre as instâncias governamentais e as não-governamentais na busca de uma cooperação técnica e política.

O Fórum Estadual de ONGs/Aids reúne 171 organizações filiadas, das quais uma média de 90 instituições participam ativamente das reuniões do grupo. Os encontros mensais, previstos em estatuto, possuem uma agenda do movimento de luta contra aids e uma agenda de articulação com as organizações governamentais.

Nas reuniões do Fórum, organizações de diversos municípios discutem os problemas locais e estabelecem estratégias de atuação. As decisões são marcadas pelo voto coletivo e as atas das reuniões, com as deliberações do grupo, são disponibilizadas no site do Fórum para que as ações possam ser monitoradas. Rubens Duda (2005), presidente do Fórum, assinala: "A estratégia é, primeiro nos articularmos entre nós, para que possamos articular com competência com estados 
e municípios" (informação verbal). ${ }^{7}$ A agenda é discutida com representantes do PEDST/Aids e PMDST/Aids de São Paulo, que prestam contas das ações governamentais nas áreas de prevenção e assistência. Do ponto de vista do Fórum de ONGs/Aids, esse diálogo mensal representa um grande avanço e um ganho significativo para o movimento social pela regularidade com que as discussões acontecem. Esse modelo de articulação intersetorial é reproduzido nos fóruns regionais, que envolvem as coordenações locais, como citado nessa descrição da atuação governamental.

Assim como foi identificado pela representante do PE DST/Aids, o representante do Fórum de ONGs/Aids aponta o Fórum de Gestores e o Grupo de Trabalho OG/ONG como importantes iniciativas políticas direcionadas para o monitoramento crítico das políticas públicas. Destacam-se, também, o assento permanente de representantes das ONGs/Aids na Comissão Municipal de São Paulo, uma experiência que está se ampliando para outros municípios do Estado.

Em nível nacional, os ativistas se fazem presentes na CNAIDS e na Comissão Nacional de Articulação dos Movimentos Sociais (CAMS). Esta última, engloba vários setores organizados da sociedade civil que, mesmo sem relação direta com o movimento específico de enfrentamento da aids, discutem as políticas para o HIV/Aids do setor, como associação de negros, de estudantes e outros. Além desses, há a participação no Comitê de Vacinas, que está trabalhando nos projetos de elaboração dos protocolos de vacina no Brasil, e o Conselho Nacional de Saúde. Essas instâncias estão regulamentadas pelo Governo Federal, com publicação em Diário Oficial e no site do Programa Nacional de DST e Aids.

\footnotetext{
${ }^{7}$ Comentário do presidente do Fórum de ONGs/Aids do Estado de São Paulo, em 2005, na entrevista concedida à autora deste trabalho.
} 
Os Fóruns Estaduais de ONG/AIDS estão presentes em todos os Estados, com níveis de articulação variados, desde o final do ano de 2004.

Dentro do âmbito de atuação das ONGs/Aids, há a Rede Nacional de Pessoas Vivendo com HIV/Aids-RNP, formada exclusivamente por pessoas portadoras do HIV/Aids. Apesar de a maioria dos grupos da RNP não estar constituída como organização jurídica, a participação de seus membros é muito ativa no movimento de luta contra aids e possui núcleos municipais, estaduais e regionais.

As ONGs/Aids e a RNP têm participação nos Fóruns de Patologias, existentes em alguns Estados, fortalecendo a criação de políticas de saúde mais ampliadas.

Outras participações do movimento ocorrem, de forma menos sistemática, nos eventos nas áreas de Justiça e de Educação, quando as organizações se fazem representar sob diferentes formas de participação, contribuindo, por vezes, no processo de organização desses eventos (DUDA, 2005).

\subsubsection{A participação das Casas de Apoio nos espaços de articulação intersetorial}

As Casas de Apoio não estão representadas como tal nesses espaços de articulação intersetorial. Giana (2005) explica que "[...] é difícil discutir Casa de Apoio, porque as Casas de Apoio se vinculam a fóruns e redes. São as representações de fóruns e redes que também representam as Casas de Apoio, que participam desses espaços" (informação verbal).

O representante do Fórum de ONGs/Aids, Rubens Duda (2005), também afirma em entrevista que é pequeno o número de instituições que tem atuação mais política e declara: 
[...] eu fui um exemplo disso; eu estive em Casa de Apoio 10 anos, durante 10 anos eu trabalhei na área de assistência, e era a terceira, junto com mais duas Casas de Apoio, que estava inserida em algum tipo de política. E foi das Casas de Apoio que surgiu o Fórum de ONGs/Aids do Estado de São Paulo. O Padre Valeriano também foi uma das pessoas fundadoras da ONG e também foi o implementador do Fórum junto com o GIV. As Casas de Apoio estavam nesse patamar direto, tanto que a gente acabou sendo presidente do Fórum (no caso o Lar Bethânia, o qual eu representava). A gente sentia que tinha um preconceito dentro do próprio preconceito, ou seja, dentro do mundo da aids, onde há preconceito, há preconceito contra as Casas de Apoio. Existiam organizações de prevenção que tinham um certo isolamento contra organizações que trabalhavam com assistência. Não havia afinidade, e a gente se aproximou exatamente para poder dizer: 'Olha, tanto a assistência é prevenção, quanto prevenção é assistência, então podemos estar juntos nisso e implementando políticas contra isso'.

No município de São Paulo, há o Grupo de Trabalho de Casas de Apoio, composto por uma pessoa da área de articulação com a sociedade civil e uma da área de assistência, duas pessoas da Secretaria Municipal de Assistência Social e duas pessoas do movimento de aids ligadas à Casa de Apoio. Esse grupo discute as diretrizes com relação às Casas de Apoio e o trabalho a ser executado. O município não possui uma política de financiamento específico para as organizações da sociedade civil, mas realiza apoios pontuais a ações relevantes desenvolvidas pelas organizações, incluindo as realizadas por Casas de Apoio. Não existe uma rubrica no orçamento do PM DST/Aids para fazer um repasse de recursos às Casas de Apoio, por exemplo, para compra direta de equipamentos. Os recursos repassados são feitos apenas por meio de projetos, da mesma forma como é repassado para as demais ONGs. No entanto, registra-se uma maior integração entre os serviços especializados de saúde e as Casas de Apoio, que se dá com uma maior participação delas nos Conselhos Gestores das Unidades (HENGLES, 2005). 


\subsection{ESTRATÉGIAS DE INCORPORAÇÃO DAS DEMANDAS DA SOCIEDADE CIVIL ORGANIZADA NAS POLÍTICAS PÚBLICAS PARA AS DST/HIV/AIDS}

A participação dos atores governamentais e não-governamentais, desde o início das discussões sobre a formulação das políticas, tem possibilitado que as ações atendam aos interesses dos diversos atores envolvidos no processo. Exemplo disso foi a elaboração, a partir de solicitação do Ministério da Saúde, de um plano estadual para Casas de Apoio, com vistas ao financiamento dessas instituições com recursos públicos. Esse plano foi elaborado com a participação de Estados, municípios, representação de fóruns e redes e, à medida que estava sendo discutido, foi apresentado à Comissão Bipartite. O entendimento da representante do PE DST/AIDS é a de que o plano foi aprovado porque, desde o início, teve sua estratégia discutida com todos os representantes, incorporando, desde a fase de planejamento, as demandas dos setores envolvidos. Destaca que, nos municípios inseridos na política de incentivo, a participação ampla deve advir do amadurecimento do trabalho, pois nem todos possuem Organizações NãoGovernamentais estruturadas e a articulação intersetorial está se iniciando.

Em nível municipal, as discussões seguem o modelo do PE DST/AIDS, propiciando a participação de diferentes atores na construção das propostas de trabalho, com representações governamentais e não-governamentais, e incorporando as demandas desses setores (GIANA, 2005).

Por outro lado, o representante do Fórum de ONGs/Aids aponta a necessidade de que os ativistas façam um monitoramento mais sistemático da execução das ações planejadas tanto quanto no planejamento. Como estratégia de acompanhamento eficaz, há a participação crescente de pessoas vivendo com aids 
na Ouvidoria do CRT, nos Conselhos Municipais e Estaduais de Saúde, além do site do Fórum de ONGs/Aids, que são espaços importantes de reivindicação dessa população. No Estado de São Paulo, as instâncias governamentais têm feito, muitas vezes, os ajustes solicitados a partir das demandas da sociedade civil (DUDA, 2005).

\subsection{INTERAÇÃO DO GESTOR ESTADUAL DO SUS COM ORGANISMOS INTERNACIONAIS}

A interação com os organismos internacionais acontece apenas no âmbito do Ministério da Saúde. Diferente do nível federal, no Estado, o vínculo com agências internacionais é bem menor, embora muitas dessas parceiras resultem em projetos que serão executados com a participação dos Estados e municípios (GIANA, 2005).

\subsection{RELEVÂNCIA DAS CASAS DE APOIO NO CONTEXTO DA ASSISTÊNCIA ÀS PESSOAS PORTADORAS DE HIV NO ESTADO DE SÃO PAULO}

Os entrevistados assinalam a importância das Casas de Apoio a partir das experiências construídas ao longo da epidemia.

Sobre esse aspecto, Giana (2005), do PE DST/AIDS, destaca a história da casa Brenda Lee que recebeu recursos da Secretaria de Estado da Saúde por meio de um contrato de financiamento, no período de 1988 a 2001 :

Eu considero um marco a Secretaria do Estado da Saúde, em 1988, repassar para uma Casa de Apoio, administrada por um travesti, com todo o preconceito da sociedade que existia naquela época [...]. Eu entendo que ela é um símbolo para este processo, nesse período que a gente viveu, que 
eu vivi, um período de muito conflito em que a gente vivia uma situação de pacientes vindo a óbito rapidamente. O número de óbitos/dia no Estado era um número brutal, pessoas excluídas da sociedade, que a Brenda ficou nesse início com as pessoas excluídas da sociedade, ao extremo [...]. A possibilidade de a Secretaria repassar recurso para essa Casa, aqui no município de São Paulo, foi tremendamente estratégico. Estratégico no que diz respeito a acolher as pessoas que não tinham como viver, não tinham qualquer acesso às mínimas condições de vida. Então, esse período do final dos anos 80, a Casa de Apoio Brenda Lee, eu vejo com muito respeito e lembro desse período como um período muito importante para dar conta de uma melhor qualidade de vida dessas pessoas que vivam muito pouco. $E$ o número de óbitos da Casa de Apoio, nesse período, era muito grande. E esse vinculo do programa, do Centro de Referência com a Casa de Apoio, se estabelece nesse período (Informação verbal).

A partir dos anos 90 , as pessoas passaram a ter melhores condições de vida, e a Igreja assume uma importância muito grande na implantação de Casas de Apoio, principalmente no Estado de São Paulo, com abertura de Casas de Apoio para crianças, Casas de Apoio para mulheres, Casas de Apoio que procuram dar conta das necessidades conforme a epidemia foi mudando ao longo da década de 90 .

Os recursos do Acordo de Empréstimo do Banco Mundial representaram um grande diferencial nas possibilidades de financiamento para as organizações da sociedade civil. Embora não fossem específicos para as casas de Apoio, várias dessas instituições se inseriram no financiamento a partir de projetos. No entanto, o encerramento dos projetos deixava uma lacuna nesse repasse, com conseqüente descontinuidade nas ações. Os projetos eram financiados pelo Ministério da Saúde, muitas vezes sem um vínculo com o município ou mesmo com os Estados onde eram executados. A discussão atual é sobre a possibilidade de financiamento das Casas de Apoio com recursos do Sistema Único de Saúde.

Como resposta à questão do reconhecimento, Rubens Duda (2005) também assinala algumas parcerias feitas no início da epidemia, quando profissionais de saúde do Hospital Emílio Ribas faziam visitas às Casas de Apoio para prestar assistência aos doentes. Destaca que, do ponto de vista dos ativistas, apesar da 
grande importância dessas ações, havia a preocupação de que os serviços se estruturassem para atender mais adequadamente essas pessoas em situação de exclusão.

A criação da Portaria de Casas de Apoio também foi um marco à medida que conseguiu delimitar o papel das Casas de Apoio, pondo fim a uma discussão que vinha ocorrendo entre as Casas de Apoio e os órgãos governamentais a respeito do enquadramento das casas como centros de saúde ou centros sociais.

Outro evento que lançou, no Estado de São Paulo, um olhar mais dirigido para os problemas enfrentados pelas instituições foi o Encontro Estadual de Casas de Apoio, realizado em 2002.

Todos os entrevistados reconhecem o papel fundamental desempenhado pelas Casas de Apoio no controle da infecção pelo HIV, em especial na melhora da qualidade de vida das pessoas. As Casas de Apoio têm acolhido os pacientes com aids, oferecendo assistência e facilitando o acesso aos serviços de saúde governamentais, minimizando os agravos físicos e psíquicos das pessoas que passam por longos períodos nos hospitais. No entanto, para que o reconhecimento da parceria seja efetivo, é necessário que o governo participe ativamente no financiamento das ações desenvolvidas pelas Casas de Apoio para pessoas vivendo com o HIV/Aids. 


\section{AS CASAS DE APOIO EM HIV/AIDS}

\subsection{CONCEITUAÇÃO}

Nesse contexto de respostas, registra-se o surgimento das Casas de Apoio para portadores de HIV/Aids, que se constituíram numa estratégia de resposta à precariedade dos serviços sociais e de saúde oferecidos pelo Estado. A falta de documentação sistematizada e de trabalhos científicos sobre esse tema impossibilita o desenvolvimento de uma pesquisa bibliográfica que resgate o histórico do surgimento das Casas de Apoio no Brasil. O documento produzido pela Coordenação Nacional de DST/Aids, intitulado Casas de Apoio em HIV/Aids: Guia de Recomendações, relata que as Casas de Apoio surgiram de iniciativas de instituições religiosas com o objetivo de oferecer assistência biopsicossocial às pessoas carentes e a segmentos populacionais historicamente discriminados e estigmatizados, como homossexuais, travestis, usuários de drogas, crianças e egressos do sistema carcerário.

Pelo apoio e assistência aos doentes, promovem sua (re)integração à família e ou à sociedade e buscam, cada vez mais, melhorar a qualidade de vida dessas pessoas. Os serviços oferecidos são bastante diversificados e vão desde o atendimento às necessidades básicas - de abrigo, alimentação, higiene - até cuidados terapêuticos complementares às ações desenvolvidas pelos serviços governamentais de assistência social e de saúde. O Guia de Recomendações para Casas de Apoio em HIV/Aids foi elaborado com o objetivo de estabelecer algumas diretrizes que pudessem contribuir para melhorar o funcionamento e a qualidade de assistência prestada pelas Casas às pessoas atendidas e constitui-se, também, num 
reconhecimento da contribuição social dessas instituições comunitárias ao Sistema Único de Saúde e a toda a sociedade.

Conforme definição da Coordenação Nacional de DST/Aids, são denominadas Casas de Apoio as instituições que oferecem atenção às pessoas vivendo com HIV/Aids que, por motivos de natureza social, necessitam de moradia provisória ou permanente. Essas casas devem oferecer atendimento às necessidades básicas do indivíduo e suporte à sua condição de soropositividade, como garantia de manutenção do tratamento, inserção familiar, apoio com relação aos direitos sociais e trabalhistas, lazer, apoio psicológico. As Casas de passagens são instituições de abrigo provisório a portadores de HIV/Aids em trânsito nos Estados ou municípios, fora do domicílio, para viabilizarem tratamento. Essas casas devem oferecer alimentação, condições básicas de higiene e repouso. Também podem oferecer atividades educativas relacionadas com a prevenção, apoio ao tratamento e promoção à saúde e cidadania durante o tempo de permanência provisória do usuário.

No Estado de São Paulo, a Portaria Conjunta 2CVS/CRT-DST/AIDS, de 2811-2001 (SÃO PAULO, 2001), que trata das condições de funcionamento das Casas de Apoio e Solidariedade para Portadores do Vírus da Imunodeficiência Humana e da Síndrome da Imunodeficiência adquirida, assim define as Casas de Apoio:

Artigo 5ㅇ - Casa de Apoio para Pessoas portadoras do Vírus da Imunodeficiência Humana - HIV - e para Portadores da Síndrome da Imunodeficiência Adquirida - SIDA-AIDS, ou, Casa de Apoio para Portadores de HIV/AIDS e Casa de Apoio para Crianças e Adolescentes Portadores de HIV/AIDS ou, simplesmente, Casas de APOIO para Portadores de HIV/AIDS (Grifo do autor):

São os estabelecimentos de interesse direto à saúde, públicos ou privados, destinados especificamente à prestação de assistência a portadores de HIV/AIDS, com denominações diversas, dotados de ambientes físicos, instalações e equipamentos necessários para o atendimento de pessoas infectadas pelo HIV (soropositivas para o HIV) assintomáticas e pessoas que já apresentaram sintomas e sinais da AIDS, sob regime de internato ou 
não, durante um período de tempo indeterminado, sendo que tais estabelecimentos devem dispor de quadro de funcionários próprio e, se for o caso,também voluntários para prestar cuidados à saúde, responsabilizar-se pelas atividades de higiene, alimentação, lazer, segurança e bem-estar dos usuários e, ainda, desenvolver outras atividades características da vida institucional.

Parágrafo Único - A prestação de assistência a portadores de HIV/AIDS, por parte das Casas de Apoio, não se confunde com a assistência especializada e complexa prestada por hospitais e ambulatórios médicos, já que as atividades das Casas de Apoio, primordialmente, objetivam facilitar a reintegração de pacientes no seu núcleo familiar e na comunidade e, ainda, a retomada ou o início do desenvolvimento de atividades laborais.

Além dessas e de outras definições, a Portaria estabelece uma classificação

para os estabelecimentos de interesse à saúde que atendem portadores do

HIV/Aids, agrupados no documento sob as seguintes denominações: Centro de

Convivência, Casa de Apoio Tipo I, Casa de Apoio Tipo II, Casa de Apoio para

Crianças e Adolescentes e Casa de Solidariedade às Crianças e aos Adolescentes.

Em relação às Casas de Apoio, encontramos:

Artigo 16 - CASA DE APOIO TIPO I: é o estabelecimento de interesse à saúde destinado a abrigar pessoas adultas portadoras assintomáticas do HIV e pessoas adultas que tenham apresentado os primeiros sintomas e sinais da AIDS, com ausência ou pequena dificuldade de locomoção, que necessitem de assistência psicossocial, uso de equipamentos com finalidades terapêuticas (inalador portátil e equipamento de complexidade tecnológica assemelhada) e cuidados especiais.

Artigo 17 - CASA DE APOIO DE TIPO II: é o estabelecimento de interesse à saúde destinado a abrigar pacientes com Síndrome da Imunodeficiência Adquirida, com alto grau de dependência, que apresentem sintomatologia e necessitem de cuidados especiais, porém que não exijam equipamentos para a manutenção de funções vitais.

[...]

Artigo 19 - CASA DE APOIO PARA CRIANÇAS E ADOLESCENTES: é o estabelecimento de interesse à saúde destinado a abrigar crianças e adolescentes portadores assintomáticos do HIV e crianças e adolescentes que tenham apresentado os primeiros sintomas e sinais da AIDS, com ausência ou pequena dificuldade de locomoção, que necessitem de assistência psicossocial, uso de equipamentos com finalidades terapêuticas (inalador portátil e/ou equipamento de complexidade tecnológica assemelhada) e cuidados especiais (SÃO PAULO, 2001).

A Portaria em questão foi submetida à Consulta Pública, e o processo de elaboração privilegiou as contribuições das partes mais interessadas no documento, 
como técnicos da área de saúde, vigilância sanitária e representantes de organizações da sociedade civil.

\subsection{DISTRIBUIÇÃO DAS CASAS DE APOIO NO BRASIL}

Em 2003, O Programa Nacional de DST e Aids passou a investir mais esforços às Casas de Apoio e, a exemplo da iniciativa do Estado de São Paulo, realizou um cadastro nacional das Casas de Apoio. O estudo teve como objetivo conhecer o custo médio necessário para manutenção das atividades desenvolvidas por essas casas e foi realizado nos 27 Estados, disponibilizando informações sobre a capacidade de atendimento e o custo médio/mês de manutenção. Outro objetivo foi dar maior visibilidade à sociedade com relação às oportunidades de apoio social e de promover o estabelecimento de uma rede interativa entre essas organizações, para que possam atuar de forma integrada e complementar às ações governamentais. ${ }^{8}$

A classificação das casas de Apoio em Tipo I e II possibilitou identificar a existência, no País, de 145 Casas de Apoio a um custo médio/mês de $R \$ 400,00$ para cada Casa de Apoio do tipo I e $R \$ 700,00$ para Casas de Apoio do tipo 2 e um total de 3.625 acomodações/mês (média Brasil de 25 acomodações por Casa) (FUNDAÇÃO OSWALDO CRUZ, 2006).

O banco de dados referente às Casas de Apoio identificadas em todo o País totalizou 260 instituições, distribuídas em 20 Estados brasileiros, que atendem exclusivamente pessoas portadoras do HIV/Aids (Tabela 1).

\footnotetext{
${ }^{8}$ A definição do objetivo encontra-se no formulário utilizado para coleta de dados, elaborado pela Coordenação Nacional de DST/Aids.
} 
Tabela 1. Localização geográfica das Casas de Apoio em HIV/Aids no Brasil

\begin{tabular}{|c|c|c|}
\hline Estado/Região & $\begin{array}{c}\text { Número de Casas de } \\
\text { Apoio }\end{array}$ & Percentual \\
\hline \multicolumn{3}{|l|}{ Região Sudeste } \\
\hline Espírito Santo & 10 & 3,85 \\
\hline Minas Gerais & 04 & 1,54 \\
\hline Rio de Janeiro & 18 & 6,92 \\
\hline São Paulo & 66 & 25,40 \\
\hline Total & 98 & 37,71 \\
\hline \multicolumn{3}{|l|}{ Região Nordeste } \\
\hline Alagoas & 05 & 1,92 \\
\hline Ceará & 14 & 5,40 \\
\hline Maranhão & 08 & 3,08 \\
\hline Paraíba & 02 & 0,76 \\
\hline Pernambuco & 06 & 2,30 \\
\hline Piauí & 02 & 0,76 \\
\hline Total & 37 & 14,22 \\
\hline \multicolumn{3}{|l|}{ Região Centro-Oeste } \\
\hline Goiás & 04 & 1,53 \\
\hline Mato Grosso & 07 & 2,70 \\
\hline Mato Grosso do Sul & 07 & 2,70 \\
\hline Distrito Federal & 05 & 1,92 \\
\hline Total & 23 & 8,85 \\
\hline \multicolumn{3}{|l|}{ Região Sul } \\
\hline PR & 29 & 11,15 \\
\hline Rio Grande do Sul & 31 & 11,92 \\
\hline Santa Catarina & 36 & 13,85 \\
\hline Total & 96 & 36,92 \\
\hline \multicolumn{3}{|l|}{ Região Norte } \\
\hline Amazonas & 02 & 0,76 \\
\hline Pará & 01 & 0,38 \\
\hline Tocantins & 03 & 1,16 \\
\hline Total & 06 & 2,30 \\
\hline
\end{tabular}

Nota: *Na Região Norte, nos Estados do Acre, Amapá, Roraima e Rondônia, não foram identificadas Casas de Apoio em HIV/Aids. Na Região Nordeste, os Estados do Rio Grande do Norte, Sergipe e Bahia também não possuíam casas de apoio até a data do cadastro. 
Observa-se uma maior concentração de casas de apoio nas Regiões Sul e Sudeste do País, onde também estão concentrados os casos de aids notificados. Essas regiões registram um percentual de 17,5\% e 65\% do total de casos do País, respectivamente, e concentram os serviços assistenciais com melhor infra-estrutura.

\subsection{CARACTERIZAÇÃO DAS CASAS DE APOIO DO ESTADO DE SÃO PAULO}

Em outubro de 2002, a Coordenação Estadual de DST/Aids de São Paulo realizou o I Encontro Estadual de Casas de Apoio, com o objetivo de propor diretrizes para o encaminhamento de ações em parceria entre Organizações Governamentais (OG) e ONGs, com vistas à minimização dos problemas vivenciados e otimização do trabalho dessas organizações. Durante o processo de organização do evento, o Grupo de Trabalho, composto por representantes do governo, por meio da CE DST/AIDS, e de representantes do Fórum ONG/Aids do Estado de São Paulo, observou a necessidade de se conhecer melhor essas organizações e sistematizar informações que pudessem ser socializadas para os serviços de saúde, as próprias casas, e usuários dos serviços. Para tanto, foi solicitado às Casas que respondessem a um cadastro que acompanhou as fichas de inscrição para o evento. A partir de informações já existentes na Coordenação Estadual e com informações de representantes do Fórum Estadual de ONGs/Aids, foram identificadas, à época, 61 Casas de Apoio no Estado de São Paulo, sendo 23 destas instaladas na Capital.

O cadastro apontou, ainda, entre outros, aspectos da situação legal, características de funcionamento e os principais problemas enfrentados pela Casas de Apoio.

Para realizar o levantamento dos dados no Estado, foi utilizada metodologia de entrevista presencial, tendo sido selecionados e treinados profissionais que já 
atuavam em serviços de atendimento às pessoas portadoras do HIV/Aids. Foram visitadas e entrevistadas as instituições identificadas pelos programas estaduais e municipais à época do cadastramento.

O questionário de entrevista foi dividido em blocos com dados de identificação, organização jurídico-administrativa, observações do entrevistador a respeito da conservação do imóvel e higiene dos espaços, fontes de recursos, população atendida, serviços/ações/atividades oferecidos aos usuários/moradores e outras informações. A apresentação dos dados, no entanto, não obedece rigorosamente a essa divisão de temas.

Não há referência específica à qualidade dos serviços, uma vez que esse item não foi objeto de estudo.

\subsubsection{Distribuição geográfica das Casas de Apoio no Estado de São Paulo}

Foram identificadas e cadastradas 66 Casas de Apoio em HIV/Aids no Estado de São Paulo, o que representa $25,40 \%$ de todas as casas do País (Tabela 2).

A Capital concentra 25 casas, 37,9\% do número de casas do Estado; a Região Metropolitana conta com 19 casas (28,8\%) distribuídas em 11 municípios, e 22 casas (33,3\%) estão localizadas no interior, distribuídas em 12 municípios.

Tabela 2. Casas de Apoio segundo Capital, Região Metropolitana e municípios do interior

\begin{tabular}{lcc}
\hline \multirow{2}{*}{ Localização } & \multicolumn{2}{c}{ Casas de Apoio } \\
\cline { 2 - 3 } & Número & $\%$ \\
\hline Capital & 25 & 37,9 \\
Região Metropolitana & 19 & 28,8 \\
Municípios do interior & 22 & 33,3 \\
\hline Total & 66 & 100,0 \\
\hline
\end{tabular}


Em relação ao porte dos municípios, apenas quatro municípios possuem menos de 100.000 habitantes. Destaca-se o fato de Carapicuíba, com 375.859 habitantes, possuir o mesmo número de Casas (5) que Campinas, com 1.031.887 habitantes. Campinas encontra-se em 4º lugar no ranking dos 100 municípios com maior número de casos de aids (3.908 casos) e Carapicuíba está em 21ํo lugar (812 casos), segundo dados do Boletim Epidemiológico da Coordenação do Programa Estadual de DST/Aids de São Paulo, para o período de 1980-2004 (PROGRAMA NACIONAL DE DST E AIDS 2004, 2003) (Tabela 3).

Tabela 3. Número de Casas de Apoio por município

\begin{tabular}{lcc}
\hline Município & Número de casas de apoio & População* \\
\hline São Paulo & 25 & 10.927 .985 \\
Campinas & 5 & 1.045 .706 \\
Carapicuíba & 5 & 382.772 \\
Guaratinguetá & 3 & 1110673 \\
Osasco & 3 & 705.450 \\
Ribeirão Preto & 3 & 551.312 \\
Santos & 3 & 418.316 \\
Americana & 1 & 200.607 \\
Barueri & 1 & 256.824 \\
Cajamar & 1 & 61.421 \\
Cotia & 2 & 175.008 \\
Indaiatuba & 1 & 175.933 \\
Jacareí & 1 & 208.471 \\
Lagoinha & 1 & 5.159 \\
Mairiporã & 2 & 72.750 \\
Mogi das Cruzes & 1 & 365.993 \\
Peruíbe & 1 & 63.153 \\
Santo André & 1 & 669.592 \\
São Carlos & 1 & 214.786 \\
São Vicente & 1 & 325.437 \\
São Bernardo do Campo & 1 & 788.560 \\
Sorocaba & 1 & 565.180 \\
Suzano & 1 & 272.452 \\
Taboão da Serra & 1 & 221.176 \\
\hline Total & 66 & \\
\hline & & \\
\hline
\end{tabular}

Fonte:IBGE, 2006. 


\subsubsection{Organização jurídico-administrativa}

A organização jurídico-administrativa das casas de apoio (Tabela 4) destaca que $100 \%$ das instituições possuem registro formal, sendo 50 casas $(75,8)$ classificadas como fundação privada, 11 delas (16,7\%) como Associação (OSC) e apenas três como OSCIP.

Tabela 4. Organização jurídico-administrativa de Casas de Apóio do Estado de São Paulo

\begin{tabular}{|c|c|c|}
\hline Variáveis & № & $\%$ \\
\hline \multicolumn{3}{|l|}{ Situação Jurídica } \\
\hline Fundação pública & 1 & 1,5 \\
\hline Fundação privada & 50 & 75,8 \\
\hline OSC - Associação & 11 & 16,7 \\
\hline OSC - Outra & 1 & 1,5 \\
\hline OSCIP & 3 & 4,5 \\
\hline \multicolumn{3}{|l|}{ Forma de organização } \\
\hline Por Estatuto & 41 & 62,1 \\
\hline Por Regimento Interno/Regulamento & 2 & 3,0 \\
\hline Estatuto + Regimento & 21 & 31,8 \\
\hline Outras & 2 & 3,0 \\
\hline \multicolumn{3}{|l|}{ Possui registro } \\
\hline Conselho Municipal de Saúde & 3 & 4,5 \\
\hline Conselho de Assistência Social & 7 & 10,6 \\
\hline Conselho da Criança e do Adolescente & 6 & 9,1 \\
\hline Cartório & 19 & 28,8 \\
\hline Municipal + Conselho de Assistência Social & 3 & 4,5 \\
\hline $\begin{array}{l}\text { Conselho de Assistência Social e da Criança e } \\
\text { Adolescente }\end{array}$ & 10 & 15,2 \\
\hline Não possui registro em Conselhos & 18 & 27,3 \\
\hline \multicolumn{3}{|l|}{ Registro de utilidade pública } \\
\hline Sim, Federal & 7 & 10,6 \\
\hline Sim, Estadual & 1 & 1,5 \\
\hline Sim, Municipal & 11 & 16,7 \\
\hline Sim, Federal + Municipal & 4 & 6,1 \\
\hline Sim, Federal + Estadual + Municipal & 19 & 28,8 \\
\hline Não & 24 & 36,4 \\
\hline
\end{tabular}


A forma de organização mais comum é por meio de estatutos e regimentos internos, utilizados isoladamente ou em conjunto. Um número de 41 casas $(62,1 \%)$ possui estatuto e 21 casas $(31,8 \%)$ utilizam estatuto e regimento internos como forma de organização de suas atividades.

Mais da metade das Casas de Apoio (72,7\%) possui registro em Conselhos Municipais de Saúde, de Assistência Social e ou da Criança e do Adolescente; 24 instituições, que representam $36,4 \%$ do total, não possuem registro de utilidade pública, e dezenove entidades (28,8\%) possuem certificação nas três esferas de governo.

\subsubsection{Estrutura física}

É interessante observar, na Tabela 5, que, apesar das dificuldades de sobrevivência enfrentadas pelas instituições, 31 delas (47\%) possuem imóvel próprio, em sua maioria obtido por meio de doações filantrópicas. Outras dez instituições funcionam em imóvel cedido (15,2\%) e apenas 19 casas $(28,8 \%)$ pagam aluguel. A condição física do imóvel foi considerada boa e excelente em $72,7 \%$ das instituições; $12,1 \%$ delas classificaram como aceitável e o mesmo número foi descrito como imóvel em estado precário. Em 3,0\% das instituições, o estado do imóvel não foi classificado.

Outro aspecto investigado diz respeito aos meios de locomoção utilizados pelas instituições não apenas para dar suporte administrativo as casas, mas, principalmente, pela necessidade de deslocamento constante dos pacientes para consultas médicas e para resolver questões pessoais. Constata-se que 47 instituições $(71,2 \%)$ possuem veículo próprio e as demais utilizam ônibus, carro pessoal e outros meios. 
Tabela 5. Bens de Casas de Apoio do Estado do Estado de São Paulo

\begin{tabular}{lcc}
\hline Variáveis & No & $\%$ \\
\hline Condição do imóvel & & \\
Próprio & 31 & 47,0 \\
Alugado & 19 & 28,8 \\
Cedido & 10 & 15,2 \\
Outros & 6 & 9,1 \\
Estado do imóvel & & \\
Precário & 8 & 12,1 \\
Aceitável & 8 & 12,1 \\
Boa & 28 & 42,4 \\
Excelente & 20 & 30,3 \\
lgnorado & 2 & 3,0 \\
Meio de locomoção & & \\
Veículo próprio & 47 & 71,2 \\
Ônibus & 8 & 12,1 \\
Carro pessoal & 2 & 3,0 \\
Outros & 9 & 13,6 \\
\hline
\end{tabular}

\subsubsection{Fontes de recursos}

A Tabela 6 apresenta as fontes de recursos utilizadas pelas Casas de Apoio. A solidariedade das pessoas da comunidade é importante fonte de custeio das despesas mensais, tanto como fonte principal como complementar. A maioria das casas capta recursos com pessoas físicas, seja por meio de doação direta, seja por renda de eventos e sorteios diversos.

Mesmo havendo uma variedade nas fontes de financiamento - o que poderia sugerir uma preocupação das instituições com sua sustentabilidade - observa-se, na Tabela 7, uma defasagem entre os recursos disponíveis e as despesas mensais em 29 instituições (43,9\%).

Um reduzido número de entidades (7 Casas - 10,6\%) tem o Estado entre suas principais fontes de recursos. Esse número aumenta significativamente quando os recursos governamentais aparecem como "outras fontes" (Tabela 7). 
Apenas uma Casa de Apoio informou que utilizou a produção comercial dos seus usuários como principal fonte de financiamento das despesas correntes.

Tabela 6. Fontes de recursos às Casas de Apoio do Estado de São Paulo

\begin{tabular}{lcc}
\hline Variáveis & & \\
\hline Principal fonte de recursos & No & \\
Governo Estadual & 2 & 3,0 \\
Governo Municipal & 5 & 7,6 \\
Fontes Internacionais & 5 & 7,6 \\
Produção comercial dos usuários & 1 & 1,5 \\
Doações/convênios com pessoas jurídicas & 9 & 13,6 \\
Doações de pessoas físicas & 24 & 36,4 \\
Arrecadação por meio de eventos & 3 & 4,5 \\
Rifas, bingos e assemelhados & 15 & 22,7 \\
Ignorado & 2 & 3,0 \\
Outras fontes de recursos & & \\
Coordenação Nacional de DST e Aids & 11 & 16,7 \\
Outros Órgãos do Governo Federal & 3 & 4,5 \\
Governo Estadual & 10 & 15,2 \\
Governo Municipal & 22 & 33,3 \\
Fontes Internacionais & 21 & 31,8 \\
Produção comercial dos usuários/moradores & 10 & 15,2 \\
Contribuições financeiras dos usuários/moradores ou familiares & 22 & 33,3 \\
Doações/convênios com pessoas jurídicas & 34 & 51,5 \\
Doações de pessoas físicas & 65 & 98,5 \\
Arrecadação por meio de eventos & 50 & 75,8 \\
Rifas, bingos e assemelhados & 26 & 39,4 \\
Recursos & & \\
Até 5.000 & 21 & 31,8 \\
De 5.001 a 10.000 & 13 & 19,7 \\
De 10.001 a 20.000 & 16 & 24,2 \\
De 20.001 a 50.000 & 10 & 15,2 \\
De 50.001 a 100.000 & 1 & 1,5 \\
Mais de 100.000 & 1 & 1,5 \\
Ignorado & 4 & 6,0 \\
Despesas Até 5.000 & 18 & 27,3 \\
De 5.001 a 10.000 & 10 & 15,2 \\
De 10.001 a 20.000 & 20 & 30,3 \\
De 20.001 a 50.000 & 11 & 16,7 \\
De 50.001 a 100.000 & 2 & 3,0 \\
Mais de 100.000 & 1 & 1,5 \\
Ignorado & 4 & 6,1 \\
\hline
\end{tabular}

Nota: * Algumas Casas de Apoio podem aparecer em mais de um item das variáveis. 
Tabela 7. Relação entre receita e despesas

\begin{tabular}{llc}
\hline Recursos X Despesas & $\mathbf{N}^{\circ}$ & $\%$ \\
\hline Receita igual á despesas & 22 & 33,3 \\
Receita maior que as despesas & 11 & 16,6 \\
Receita menor que as despesas & 29 & 43,9 \\
Não informaram dados financeiros & 04 & 6,0 \\
\hline
\end{tabular}

\subsubsection{Características assistenciais}

Esse item, conforme dados da Tabela 8, compreende as características da população atendida (gênero, faixa etária, local de moradia e tipo específico de população) e status sorológico.

No Estado de São Paulo, 33 Casas (50,0\%) atendem à população adulta; 11 Casas (16,7\%), crianças; uma Casa atende adolescentes; e as demais instituições abrigam duas ou mais faixas etárias.

No que se refere à origem geográfica dos seus usuários, apenas oito instituições (12,1\%) limitam suas vagas às pessoas do próprio município onde estão situadas. Nas demais instituições, 20 Casas $(30,3 \%)$ só atendem pessoas residentes no Estado de São Paulo e 35 instituições $(53,0 \%)$ atendem pessoas de qualquer parte do País.

Em relação às características da população, observa-se que há distribuição equilibrada de vagas para os diversos segmentos populacionais. No que se refere aos transgêneros (travestis), observa-se uma mudança de comportamento das Casas de Apoio em relação a esse grupo populacional, extremamente discriminado no início da epidemia, quando o atendimento a essas pessoas era muito restrito, a 
exemplo da Casa Brenda Lee, única instituição, à época, que acolhia os travestis doentes de Aids.

Quanto ao status sorológico das pessoas atendidas, 36 instituições (55,5\%) atendem apenas pessoas portadoras do HIV e 28 Casas (42,4\%) atendem a outras populações, como filhos de pessoas soropositivas não portadoras do HIV, usuários de drogas, pessoas em situação de abandono e outros.

Tabela 8. Características da população atendida

\begin{tabular}{lcc}
\hline Variáveis & No de casas & $\%$ \\
\hline Gênero & & \\
Masculino & 11 & 16,7 \\
Feminino & 5 & 7,6 \\
Ambos & 50 & 75,8 \\
Faixa etária & 33 & 50,0 \\
Adultos & 11 & 16,7 \\
Crianças & 1 & 1,5 \\
Adolescentes & 6 & 9,1 \\
Adulto + Criança & 2 & 3,0 \\
Adulto + Criança + Adolescente & 11 & 16,7 \\
Criança + Adolescente & 2 & 3,0 \\
Adolescente + Adulto & & \\
Local de moradia & 8 & 12,1 \\
Apenas deste município & 20 & 30,3 \\
Deste e de outros municípios do Estado & 35 & 53,0 \\
De qualquer município de qualquer Estado & 3 & 4,5 \\
lgnorado & & \\
Tipo específico & 37 & 56,1 \\
Usuário de drogas & 28 & 42,4 \\
Travesti & 37 & 56,1 \\
População de rua & 26 & 39,4 \\
Pessoa com transtorno mental & 36 & 54,5 \\
Profissional do sexo & 30 & 45,5 \\
Alcoólatra crônico & 36 & 54,5 \\
Homossexual & 35 & 51,5 \\
Criança e adolescente & & \\
Estado sorológico & 36 & 54,5 \\
Todos são soropositivos & 28 & 42,4 \\
Nem todos são soropositivos & 2 & 3,0 \\
lgnorado & & \\
\hline & & \\
\hline
\end{tabular}

Nota: * Algumas Casas de Apoio podem aparecer em mais de um item das variáveis. 


\subsubsection{Tipo de encaminhamento}

Quanto ao tipo de encaminhamento, a demanda espontânea representa 34,8\% dos usuários enquanto os serviços de saúde, Unidades Básicas de Saúde (UBS) e os hospitais e órgãos da Justiça representam a ampla maioria dos encaminhamentos (Tabela 9).

Tabela 9. Procedência dos usuários segundo tipos de encaminhamento

\begin{tabular}{lcr}
\hline Variável & № & $\%$ \\
\hline Tipo de encaminhamento & & \\
Justiça & 35 & 53,0 \\
Polícia & 6 & 9,1 \\
Hospitais & 54 & 81,8 \\
Espontâneo & 23 & 34,8 \\
Bombeiros & 2 & 3,0 \\
Unidades Básicas de Saúde & 24 & 36,4 \\
Outros & 32 & 48,5 \\
\hline
\end{tabular}

\subsubsection{Capacidade de atendimento}

Os dados relativos ao número de camas estão aqui agrupados em intervalos numéricos (Tabela 10). Houve dificuldade em se definir os números globais, pois algumas instituições informaram de modo diferenciado sobre a questão relativa ao número de vagas. Existe uma variação na disponibilidade de camas que pode ir de 3 a 184 camas. Em 23 Casas (34,8\%), a oferta varia entre 11 a 20 camas e, em 18 casas $(27,3 \%)$, a oferta varia entre 21 a 50 camas. 
Tabela 10. Capacidade de atendimento segundo número de camas disponíveis, número de atendimentos/mês e tipo de permanência

\begin{tabular}{|c|c|c|}
\hline Variáveis & № & $\%$ \\
\hline \multicolumn{3}{|l|}{ Vagas } \\
\hline De 0 a 5 & 2 & 3,0 \\
\hline De 6 a 10 & 12 & 18,2 \\
\hline De 11 a 20 & 23 & 34,8 \\
\hline De 21 a 50 & 18 & 27,3 \\
\hline De 51 a 100 & 1 & 1,5 \\
\hline Mais de 100 & 1 & 1,5 \\
\hline Ignorado & 9 & 13,6 \\
\hline \multicolumn{3}{|c|}{ Atendimentos por mês } \\
\hline De 0 a 5 & 1 & 1,5 \\
\hline De 6 a 10 & 10 & 15,2 \\
\hline De 11 a 20 & 24 & 36,4 \\
\hline De 21 a 50 & 20 & 30,3 \\
\hline De 51 a 100 & 2 & 3,0 \\
\hline Mais de 100 & 7 & 10,6 \\
\hline Ignorado & 2 & 3,0 \\
\hline \multicolumn{3}{|c|}{ Tipo de permanência } \\
\hline Integral & 61 & 92,4 \\
\hline Diurno & 1 & 1,5 \\
\hline Passagem & 1 & 1,5 \\
\hline Ignorado & 3 & 4,5 \\
\hline
\end{tabular}

Os questionários informam que número total de camas existentes é superior a 1.260 (três casas não informaram o número de camas disponíveis) e o volume médio de atendimentos/mês, somadas todas as instituições que responderam a esse item, é de 2.622 atendimentos (duas casas não informaram esse dado). Em relação ao número de camas, o número mínimo é de zero e o máximo é de 70 . A variação nos atendimentos é de, no mínimo, cinco e, no máximo, 330 atendimentos/mês.

A média de atendimentos mensais de cada instituição está diretamente relacionada com o número de camas disponíveis, uma vez que $92,4 \%$ delas oferecem abrigo em tempo integral. Alguns usuários são moradores permanentes em função de sua condição de saúde e/ou social. 


\subsubsection{Atividades assistenciais}

Esses aspectos, como um todo, são de grande importância, já que o conjunto de atividades representa a complexidade das demandas sociais trazidas pelos usuários e/ou moradores das Casas de Apoio.

O apoio às necessidades humanas básicas - como abrigo, alimentação e higiene pessoal - é oferecido pela quase totalidade das Casas.

Destaca-se a administração de medicamentos, fundamental no processo de adesão às Terapias Anti-Retrovirais, além das atividades especificamente voltadas para o incentivo a essa adesão. A Tabela 11 mostra que 64 Casas $(97,0 \%)$ desenvolvem atividades voltadas para adesão ao tratamento, de forma individual e ou coletiva. Apenas sete Casas (10,4\%) informaram não realizar esse tipo de atividade. Na Tabela 13, mais à frente, no item em que as Casas de Apoio identificam seus principais problemas, apenas $16,4 \%$ das instituições relataram dificuldades com a adesão aos anti-retrovirais.

Ainda na Tabela 11, registram-se os encaminhamentos dos usuários às consultas médicas, odontológicas, psicológicas, psiquiátricas e outras especialidades, observando-se que 100\% das instituições mantém algum sistema de referência dos seus usuários para os serviços de saúde.

As atividades dirigidas estão presentes em todas as casas de Apoio, principalmente as atividades de informação, educação e capacitação (presente em $80,0 \%$ das Casas), (re)inserção social e familiar (84,6\%), lazer (oferecido em 89,2\%) e atividades de artesanato e afins (em 73,8\%).

Atividades relacionadas com a profissionalização e inserção no mercado de trabalho, apesar de representarem grandes desafios, já são executadas por 2,7\% e 
$36,9 \%$ das Casas de Apoio, respectivamente. Parte dessas atividades tem sido fomentada por projetos financiados pelos Programas Nacional e Estadual de DST/Aids.

Tabela 11. Características assistenciais segundo apoio às necessidades do dia-a-dia, atendimentos de saúde e atividades oferecidos aos usuários das Casas de Apoio do Estado de São Paulo

\begin{tabular}{|c|c|c|}
\hline Variáveis $^{\star}$ & № & $\%$ \\
\hline \multicolumn{3}{|l|}{ Apoio às necessidades do dia-a-dia } \\
\hline Abrigo diurno & 3 & 4,5 \\
\hline Abrigo noturno & 8 & 12,1 \\
\hline Abrigo diurno e noturno & 55 & 83,3 \\
\hline Todas as refeições & 64 & 97,0 \\
\hline Administração de medicamentos & 64 & 97,0 \\
\hline \multirow{2}{*}{$\begin{array}{l}\text { Encaminhamento para exames laboratoriais e consultas } \\
\text { Instalações e materiais relacionados com a higiene } \\
\text { pessoal }\end{array}$} & 62 & 93,9 \\
\hline & 64 & 97,0 \\
\hline \multicolumn{3}{|l|}{ Atendimentos de saúde } \\
\hline Consultas médicas & 28 & 54,9 \\
\hline Consultas odontológicas & 24 & 47,1 \\
\hline Consultas de psicologia & 41 & 80,4 \\
\hline Consultas de psiquiatra & 20 & 39,2 \\
\hline Outras consultas & 29 & 56,9 \\
\hline \multicolumn{3}{|l|}{ Atividades dirigidas } \\
\hline Informação, educação, capacitação & 52 & 80,0 \\
\hline Inserção social e familiar & 55 & 84,6 \\
\hline Inserção no mercado de trabalho & 24 & 36,9 \\
\hline Profissionalização & 18 & 27,7 \\
\hline Assessoria jurídica & 33 & 50,8 \\
\hline Atividades de artesanato e afins & 48 & 73,8 \\
\hline Atividades físicas & 40 & 61,5 \\
\hline Lazer & 58 & 89,2 \\
\hline Apoio/Procedimentos para adoção & 17 & 26,2 \\
\hline Outros & 26 & 40,0 \\
\hline \multicolumn{3}{|l|}{ Tipo de estímulos à adesão ao tratamento ARV } \\
\hline Individual & 22 & 33,3 \\
\hline Coletivo & 6 & 9,1 \\
\hline Ambos & 31 & 47,0 \\
\hline Não são desenvolvidos & 7 & 10,6 \\
\hline \multicolumn{3}{|l|}{ Permissão para permanência de acompanhantes } \\
\hline $\operatorname{Sim}$ & 10 & 15,2 \\
\hline Não & 56 & 84,8 \\
\hline \multicolumn{3}{|l|}{ Permissão para visitas } \\
\hline Sim & 2 & 3,0 \\
\hline Não & 64 & 97,0 \\
\hline \multicolumn{3}{|l|}{ Permissão para saídas } \\
\hline Sim & 5 & 7,6 \\
\hline Não & 61 & 92,4 \\
\hline
\end{tabular}

Nota: * Alaumas Casas de Apoio podem aparecer em mais de um item das variáveis. 
Pode-se observar, ainda, que a assessoria jurídica é oferecida por $50,8 \%$ das instituições, seja por meio do trabalho voluntário dos Operadores do Direito nas próprias instituições, seja por encaminhamentos aos órgãos públicos.

Em relação ao apoio para procedimentos de adoção, esse tipo de encaminhamento é realizado em 17 (26,2\%) das Casas, representando 56,6 das instituições que abrigam crianças, o que aponta a tentativa de não institucionalizar a permanência dos órfãos da aids nas Casas de Apoio.

Também foram identificados nesse item os critérios de permanência de acompanhantes. Das instituições, $88,8 \%$ não admitem acompanhantes, por exemplo, possíveis parceiros externos. As visitas são admitidas em apenas 3,0\% das Casas e as saídas são permitidas em 7,6\% das Casas.

$\mathrm{Na}$ Tabela 12, observa-se que há maior número de profissionais contratados nos serviços básicos, como as atividades de serviços gerais (limpeza, cozinha, lavanderia) e cuidados de enfermagem (auxiliares de enfermagem).

Observa-se, na Tabela 12, que menos de $40 \%$ das Casas de Apoio dispõem de atendimento de profissionais de saúde de nível superior, em sua maioria em caráter voluntário. Dentre esses profissionais, os psicólogos estão presentes em $65,2 \%$ das Casas, acima dos assistentes sociais (presentes em 43,9\% das instituições), médicos (presentes em $36,4 \%$ das Casas) e enfermeiros (disponíveis em 33,3 das Casas). 
Tabela 12. Quadro de profissionais das Casas de Apoio do Estado de São Paulo

\begin{tabular}{|c|c|c|c|c|c|c|c|c|}
\hline \multirow{3}{*}{ Profissional } & \multicolumn{6}{|c|}{ Tipo } & \multirow{2}{*}{\multicolumn{2}{|c|}{$\begin{array}{c}\text { Casas de } \\
\text { Apoio* }\end{array}$}} \\
\hline & \multicolumn{2}{|c|}{ Voluntário } & \multicolumn{2}{|c|}{ Contratado } & \multicolumn{2}{|c|}{ Cedido } & & \\
\hline & № & $\%$ & № & $\%$ & № & $\%$ & № & $\%$ \\
\hline Médico & 17 & 25,8 & 3 & 4,5 & 5 & 7,6 & 24 & 36,4 \\
\hline Enfermeiro & 14 & 21,2 & 9 & 13,6 & 3 & 4,5 & 22 & 33,3 \\
\hline Psicólogos & 32 & 48,5 & 12 & 18,2 & 5 & 7,6 & 43 & 65,2 \\
\hline Psiquiatra & 4 & 6,1 & 0 & 0,0 & 1 & 1,5 & 5 & 7,6 \\
\hline Assistente social & 16 & 24,2 & 12 & 18,2 & 2 & 3,0 & 29 & 43,9 \\
\hline Cirurgião-dentista & 9 & 13,6 & 3 & 4,5 & 1 & 1,5 & 13 & 19,7 \\
\hline Auxiliar de enfermagem & 13 & 19,7 & 29 & 43,9 & 6 & 9,1 & 40 & 60,6 \\
\hline Cozinheiro & 12 & 18,2 & 47 & 71,2 & 0 & 0,0 & 54 & 81,8 \\
\hline Auxiliar de cozinha & 12 & 18,2 & 15 & 22,7 & 0 & 0,0 & 25 & 37,9 \\
\hline Faxineiro & 7 & 10,6 & 34 & 51,5 & 2 & 3,0 & 40 & 60,6 \\
\hline Lavadeira & 9 & 13,6 & 33 & 50,0 & 1 & 1,5 & 41 & 62,1 \\
\hline Motorista & 10 & 15,2 & 29 & 43,9 & 0 & 0,0 & 37 & 56,1 \\
\hline Administrador & 6 & 9,1 & & & 17 & 25,8 & 20 & 30,3 \\
\hline Coordenador & 1 & 1,5 & 16 & 24,2 & 0 & 0,0 & 17 & 25,8 \\
\hline Auxiliar de coordenação & 0 & 0,0 & 2 & 3,0 & 0 & 0,0 & 2 & 3,0 \\
\hline Educador & 5 & 7,6 & 7 & 10,6 & 1 & 1,5 & 12 & 18,2 \\
\hline Fisioterapeuta & 2 & 3,0 & 3 & 4,5 & 0 & 0,0 & 5 & 7,6 \\
\hline Monitor & 1 & 1,5 & 8 & 12,1 & 1 & 1,5 & 9 & 13,6 \\
\hline Terapeuta ocupacional & 1 & 1,5 & 0 & 0,0 & 0 & 0,0 & 1 & 1,5 \\
\hline Recepcionista & 1 & 1,5 & 3 & 4,5 & 0 & 0,0 & 4 & 6,1 \\
\hline Telemarketing & 0 & 0,0 & 5 & 7,6 & 0 & 0,0 & 5 & 7,6 \\
\hline Pagens & 1 & 1,5 & 1 & 1,5 & 0 & 0,0 & 2 & 3,0 \\
\hline Outros & - & - & - & - & - & - & 28 & 42,4 \\
\hline
\end{tabular}

Nota: * Algumas Casas de Apoio podem aparecer em mais de um item da Tabela.

\subsubsection{Outras informações}

O mapeamento dos principais problemas enfrentados no trato com os usuários das Casas (Tabela 13) apontou problemas centrados no número insuficiente de profissionais especializados $(62,7 \%)$ e/ou recursos humanos insuficientes (59\%). Dificuldades na capacitação da equipe são encontradas em 
$59,7 \%$ das instituições e a falta de materiais de consumo em 55,2\% delas. Apesar dos financiamentos do Ministério da Saúde por meio de projetos, a falta de equipamentos ainda é um problema a ser enfrentado por $43,3 \%$ das organizações.

Esses dados estão de acordo com o desequilíbrio observado na Tabela 7, de despesas e receita mensal, na qual $43,2 \%$ das instituições informaram que os seus gastos são superiores ao volume de recursos captados.

A maioria das Casas de Apoio $(68,7 \%)$ afirmou já ter passado por avaliação externa em oposição aos 31,3\% que nunca foram avaliadas.

Tabela 13. Avaliação externa e principais dificuldades de Casas de Apoio do Estado de São Paulo

\begin{tabular}{lcc}
\hline Variáveis* $^{\star}$ & No & $\%$ \\
\hline Avaliação externa & & \\
Sim & 44 & 71,0 \\
Não & 18 & 29,0 \\
\hline Principais dificuldades & 9 & \\
Adesão ao tratamento ARV & 4 & 14,8 \\
Relação com os usuários & 8 & 6,6 \\
Relação entre os usuários & 40 & 13,1 \\
Número insuficiente de profissionais especializados & 34 & 65,6 \\
Equipe necessita maior capacitação & 36 & 55,7 \\
Insuficiência de recursos humanos & 25 & 59,0 \\
Falta de equipamentos & 32 & 52,0 \\
Falta de materiais de consumo & 21 & 34,4 \\
Falta de transporte próprio & 40 & 65,6 \\
Outras & & \\
\hline
\end{tabular}

Nota: * Algumas Casas de Apoio podem aparecer em mais de um item das variáveis.

Pode-se inferir, pelo conjunto das informações, que as Casas de Apoio em HIV/Aids representam uma importante modalidade de assistência complementar aos serviços assistenciais ofertados pela rede pública aos portadores de HIV/Aids, pois, 
embora o surgimento da Terapia Anti-Retroviral possibilite uma significativa melhora na qualidade de vida das pessoas, observa-se que permanece em crescimento o número dos que necessitam desse apoio para o enfrentamento da doença de forma mais digna e humana. 


\section{METODOLOGIA}

Dada a pouca informação disponível sobre o tema deste estudo, o próprio processo de coleta de dados contribuiu para a redefinição das questões relevantes para a compreensão do problema da pesquisa.

Trata-se de um estudo que se utiliza da triangulação de métodos qualitativos e quantitativos por meio de diferentes técnicas.

\subsection{BANCO DE DADOS DAS CASAS DE APOIO}

Como ponto de partida, foi feita uma análise estatística do banco de dados de Casas de Apoio, gerado pelo censo realizado pelo Programa Nacional de DST e Aids, em todo o País, a partir de material cedido pela Unidade de Sociedade Civil e Direitos Humanos (SCDH) sobre o referido programa (dados nacionais) e pela Diretoria de Assistência da CE DST/AIDS (dados das Casas do Estado de São Paulo).

No Estado de São Paulo, a organização do processo de cadastro de Casas de Apoio foi coordenado pela área de Assistência do PE DST/AIDS e contou também com a participação da área de Articulação com ONGs. Participaram do processo de organização e supervisão seis técnicos das referidas áreas. O Estado de São Paulo possui 24 DIRs e, para agilizar o processo de mapeamento e cadastro das Casas de Apoio, o Estado foi "dividido" em cinco macrorregiões. Cada técnico ficou responsável por uma macrorregião. Foram encaminhadas solicitações de indicação dos entrevistadores para quatro DIRs do interior, identificadas como estratégicas pela concentração de casas de apoio em suas regiões. A distribuição 
dos entrevistadores se deu da seguinte forma: DIR 10 - Bauru (que também ficou como pólo das regiões Araçatuba, Assis, Botucatu, Marília, Presidente Prudente, São José do Rio Preto) - 2 entrevistadores; DIR 12 - Campinas (que também ficou como pólo das regiões Piracicaba, São João da Boa Vista, Sorocaba) - dois entrevistadores; DIR 18 - Ribeirão Preto (Araraquara, Barretos e Franca) - um entrevistador; DIR 19 - Santos (Registro, São José dos Campos e Taubaté) - dois entrevistadores. Na Capital e na Grande São Paulo, houve indicação de oito entrevistadores, identificados a partir de processo seletivo conduzido pela área de Recursos Humanos do CRT-DST/Aids - SP, que constou de análise de curriculum vitae e entrevista.

Os pré-requisitos exigidos para prestação de serviços, como entrevistador, foram:
a) ser profissional da saúde;
b) possuir formação superior;
c) ter experiência na área de DST/Aids;
d) conhecer os equipamentos (Casas de Apoio e SAEs);
e) ter disponibilidade de horário;
f) possuir desejável conhecimento em pesquisa;
g) ter disponibilidade para participar do treinamento específico.

No total, atuaram no processo de coleta de dados 15 entrevistadores.

O treinamento foi realizado em 29-09-2003, no CRTA, e teve como conteúdo:

Cadastro Nacional de Casas de Apoio; Apresentação do Instrumento e orientações sobre o mapeamento; Construção de agenda para supervisão; Entrega da documentação (instrumento de pesquisa, ofício de apresentação dos entrevistadores para as Casas de Apoio e relação de Casas de Apoio e SAEs por região). 
Os entrevistadores foram orientados a entrar em contato com os SAEs de referências na região, a fim de identificarem outras Casas de Apoio que não estavam pré-relacionadas.

Por tratar-se de um cadastro de âmbito nacional, os programas estaduais de DST/Aids tinham como papel no processo apenas a operacionalização. Tendo em vista o curto prazo disponível para a realização do cadastro, o fato de que as Casas seriam visitadas e analisadas e por tratar-se de uma ação governamental, o PEDST/AIDS de São Paulo definiu que esse processo seria conduzido e executado apenas por técnicos das instâncias governamentais, a fim de evitar problemas éticos. Assim sendo, os entrevistadores deveriam ter vínculo público e eram apresentados às casas de apoio por meio de um ofício encaminhado pela doutora Maria Clara Giana, coordenadora adjunta do PE-DST/Aids.

As Casas de Apoio tinham a opção de colaborar ou não, bem como autorizar ou não a visita e a aplicação do instrumento. Todas as casas identificadas concordaram em responder ao questionário. O Fórum de ONGs/Aids foi informado sobre todo o processo e não houve questionamento sobre os procedimentos.

A elaboração do formulário do cadastro foi feita pela CN DST/Aids e contou com a colaboração de técnicos daquele programa, da CE DST/AIDS de alguns Estados e representantes das Casas de Apoio (ANEXO A).

O cadastro registrou a existência de 66 Casas de Apoio em HIV. As Casas de Passagem não foram incluídas no cadastro desse Estado por não terem a soropositividade para o HIV como um dos critérios de admissão. 


\subsection{BANCO DE INFORMANTES-CHAVE}

A coleta de dados referentes à análise do processo de formulação das políticas públicas para as DST/Aids foi feita por meio de entrevistas semiestruturadas com informantes-chave (ANEXOS B e C).

Como informantes-chave foram selecionados profissionais que possuem histórico de atuação na área de gestão das políticas públicas de DST/Aids no Estado de São Paulo, que são a coordenadora do Programa Estadual de DST/Aids, o presidente do Fórum de ONGs/Aids do Estado de São Paulo e uma representante do Programa Municipal de DST/Aids de São Paulo (responsável pelo Setor de Articulação com a Sociedade Civil Organizada).

Foram feitas entrevistas semi-estruturadas, realizadas pela autora deste trabalho, gravadas em fitas cassete (ANEXO D). Após a transcrição do material, as entrevistas foram enviadas por correio eletrônico para os entrevistados, para que fossem feitas correções no conteúdo, se necessário, e dada autorização para publicação das fontes (ANEXO E).

As entrevistas abordaram questões que, à semelhança de indicadores, nortearam a busca de respostas para as temáticas relacionadas com o objetivo de identificar e analisar a articulação intersetorial no campo de gestão das políticas de saúde para as DST/Aids. Essas temáticas enfocaram os seguintes aspectos da articulação setorial: instâncias de gestão intersetorial das políticas de DST/HIV/Aids; processo decisório nas instâncias de gestão intersetoriais das políticas de DST/HIV/Aids; eficácia da gestão intersetorial das políticas de DST/HIV/Aids; formas de atuação dos representantes da sociedade civil organizada; estratégias de incorporação das demandas da sociedade civil organizada nas políticas públicas 
para as DST/HIV/Aids; estratégias de interação do gestor estadual do SUS com os governos e organismos internacionais; eficácia da articulação do gestor estadual com os Governos e Organismos Internacionais; relevância das Casas de Apoio no contexto da assistência aos portadoras do HIV no Estado de São Paulo.

\subsection{LEVANTAMENTO BIBLIOGRÁFICO E DOCUMENTAL}

Para a contextualização dos dados trabalhados nesta pesquisa, o estudo iniciou com o levantamento de bibliografia sobre as Casas de Apoio no Brasil. Sobre esse tema, foram encontrados apenas os documentos produzidos pelo PNDST/AIDS e pela CE DST/AIDS de São Paulo e extenso material sobre as organizações do terceiro setor. 


\section{CONCLUSÃO}

O atual perfil epidemiológico do HIV/Aids no Brasil registra um aumento do número de casos de HIV/Aids entre os segmentos populacionais mais pobres. A exclusão social dessas pessoas agrava-se quando somada ao estigma e ao preconceito associado ao HIV/Aids, aumentando sua vulnerabilidade. As necessidades de assistência social, inclusive para manutenção de respostas terapêuticas realmente eficazes, tornam-se cada vez maiores, à medida que cresce o número de pessoas afetadas pelo HIV/Aids. Apesar das contribuições sociais fundamentais oferecidas pelas ONGs/Aids nas ações de prevenção e assistência às DST/HIV/Aids, com destaque para as ações assistenciais oferecidas pelas Casas de Apoio em HIV/Aids, que acolhem e cuidam de soropositivos e doentes de aids em situação de exclusão social, estas não são suficientes para atender a todos os necessitados, exigindo uma ação intersetorial, nas três esferas de governo, no sentido de se garantir a eqüidade e universalidade desses benefícios.

As ações em parceria entre sociedade civil e governo têm sido apontadas como uma das principais causas do sucesso do Programa Nacional de DST e Aids. As organizações da sociedade civil prestam papel relevante nas ações de prevenção, com consideráveis contribuições nas ações voltadas para as populações consideradas mais vulneráveis, enquanto as ações governamentais registram importante investimento nos serviços de assistência. Respeitadas as competências de cada setor da sociedade, há um somatório positivo dos esforços empreendidos por todos os atores envolvidos em todas as atividades ligadas à política de DST/HIV/Aids no Brasil. 
A Coordenação Estadual de DST/Aids de São Paulo, bem como as Coordenações Municipais têm mantido um canal de interlocução permanente com a sociedade civil, estabelecendo parcerias na execução de ações de prevenção e assistência às DST/Aids com os mais diversos segmentos sociais, como universidades, movimentos sociais e, especialmente, as chamadas ONGs/Aids. No discurso dos entrevistados deste estudo, aparece muito claramente a forte aproximação dos governos com as ONGs/Aids, num projeto de parceria no qual os atores envolvidos no cenário dessas políticas parecem comungar dos mesmos princípios e objetivos. Landim (2001, p. 7-8) observa que

[...] os discursos através do quais essas entidades definem seus objetivos é que nos dá uma idéia mais completa daquilo que as ONGs pretendem fazer. Como sempre reafirmam, não pretendem com sua ação substituir o Estado - e nem os recursos que mobilizam poderiam sugerir essa possibilidade. As experiências mencionadas, desenvolvidas na maior parte junto a grupos populares, discriminados ou marginalizados, fazem sentido, para essas entidades, na medida em que possam contribuir para a promoção de valores e de resultados como a construção da sociedade civil, a democratização, a promoção da cidadania e, cada vez mais, a interpelação do Estado no nível das políticas públicas.

Observou-se que, nos principais grupos de trabalho para proposição de políticas, há sempre participação efetiva das ONGs, embora a ação intersetorial no âmbito das instâncias governamentais ainda seja incipiente. A composição dos grupos parece buscar a diversificação de atores enquanto a interface com os municípios amadurece gradativamente. No nível municipal, o trabalho intersetorial caminha mais lentamente, talvez como conseqüência da pouca autonomia financeira, uma vez que o Estado historicamente tem descentralizado a execução das ações sem que a descentralização dos recursos acompanhe essa proposta de atuação.

Com larga experiência acumulada e buscando respostas cada vez mais efetivas, as ONGs/Aids têm desenvolvido suas ações de forma a abordar aspectos 
que ultrapassam as fronteiras do processo saúde/doença, dirigindo o seu foco também para o despertar do exercício da cidadania e para a importância do controle social na garantia de uma assistência à saúde com qualidade. Nesse sentido, cresce a participação de membros das ONGs/Aids nos Conselhos Municipais de Saúde, numa busca de diálogo com as instâncias governamentais mais próximas do contexto onde suas ações são executadas, mas com a clara compreensão de que os avanços conquistados até o momento ainda precisam ser aprimorados e ampliados, incluindo uma articulação intersetorial e o envolvimento de outros atores sociais.

A falta de visibilidade dos recursos sociais públicos disponíveis, as formas de acesso a outros programas sociais, bem como a órgãos e agentes responsáveis por esses programas dificultam a otimização das ações de assistência prestadas pelas ONG/Aids e demais organizações sem fins lucrativos que assistem as pessoas que vivem ou convivem com o HIV/Aids.

A inserção das DST/HIV/Aids na modalidade de financiamento por meio do repasse do incentivo fundo a fundo para Estados e municípios, iniciada em 2004 e efetivada em 2006, sem dúvida representa avanços na consolidação de uma política intersetorial que garanta maior racionalidade na formulação e continuidade das ações implementadas até o momento, mas não responde em agilidade e quantidade às necessidades de atenção social e à saúde das pessoas afetadas pelo HIV/Aids impostas pelos contornos e que a epidemia tem assumido.

Conhecer, compreender e caracterizar as Casas de Apoio constitui-se, neste momento, numa possibilidade de dar mais visibilidade a essas instituições e contribuir para à formulação de políticas governamentais que possibilitem não apenas o financiamento de parte das ações oferecidas por essas organizações, com 
a possível inserção na rede de financiamentos do Sistema Único de Saúde, como identificar as suas necessidades de apoio técnico, melhorando a qualidade da assistência e possibilitando, assim, a manutenção de uma parceria, histórica e importante, entre sociedade civil e governo, no enfrentamento da epidemia de Aids no Brasil. É importante que o "[...] reconhecimento do caráter público e não-lucrativo da ação das ONGs se traduza em maior acesso, para essas entidades, aos benefícios previstos na legislação quanto às entidades de educação e assistência social "(LANDIM, 2001, p. 2). 


\section{REFERÊNCIAS}

Altman D. Poder e comunidade: respostas organizacionais e culturais à Aids. Rio de Janeiro: Relume-Dumará; 1995.

Barbosa PR, coordenador. Hospitais filantrópicos no Brasil. Rio de Janeiro: BNDES; 2002. Checar no texto

Basso CR. A qualidade da assistência aos portadores de HIV/Aids nos serviços descentralizados do Estado de São Paulo [dissertação]. São Paulo: Faculdade de Saúde Pública, Universidade de São Paulo; 1999.

Basso CR. Programa de DST/Aids no SUS. In: Negri B, Viana ALD, organizadores. O Sistema Único de Saúde em 10 anos de desafio. São Paulo: Sobravime; 2002.

Brasil. Ministério da Saúde. Aids II: relatório de implementação e avaliação. dezembro de 1998 a maio de 2001. Acordo de Empréstimo - Bird 4392/ BR. Disponível em: http://nweb18.worldbank.org/oed/oeddoclib.nsf/24cc3bb1f94ae11c 85256808006a0046/252e995c6539cd6f85256f65007daaf3/\$FILE/ppar_28819_portu guese.pdf. Acesso: 14 maio 2006.

Brasil. Ministério da Saúde. Coordenação Nacional de DST e Aids. Guia de recomendações: casa de apoio em HIV/Aids. Brasília; 1997.

Brasil. Ministério da Saúde. Relatório final: prevenção e controle das doenças sexualmente transmissíveis e Aids. Brasília: Coordenação Nacional de DST e Aids/ Asplav; 1999.

Camargo Junior RK. Políticas públicas e prevenção em HIV/Aids. In: Parker R, Galvão J, Bessa MS, organizadores. Saúde, desenvolvimento e política: respostas frente a Aids no Brasil. São Paulo: Ed. 34; 1999.

Carneiro Junior NA O setor público não estatal: as organizações sociais como possibilidades e limites na gestão pública da saúde [tese]. São Paulo: Faculdade de Medicina da Universidade de São Paulo, Departamento de Medicina Preventiva; 2002. p. 29-57.

Cohn A, Elias PEM. Saúde no Brasil: políticas e organização de serviços. 5. ed. rev. São Paulo: Cortez; 2003.

Daniel H, Parker R. AIDS: a terceira epidemia. São Paulo: Iglu; 1991. 
Eco U. Como se faz uma tese. 14. ed. São Paulo: Perspectiva; 1996.

Elias PEM. Reforma ou contra-reforma na proteção social à saúde. Lua Nova. 1997;40/41:193-216.

Falconer AP, Vilela R. Recursos privados para fins públicos: Grantmakers brasileiras. São Paulo: Fundação Peiropolis; Grupo de Institutos Fundações e Empresas, 2001.

Fernandes RC. Privado porém público: o terceiro setor na América Latina. Rio de Janeiro: Relume-Dumará; 1994.

Ferreira VSC, Silva LMV. Intersetorialidade em saúde: um estudo de caso. In: Hartz ZMA, Silva LMV, organizadores. Avaliação em saúde: dos modelos teóricos à prática na avaliação de programas e sistemas de saúde. Salvador: EDUFBA; 2005. p. 103150.

Fundação Oswaldo Cruz. Nota técnica. Disponível em: http://cedoc.ensp.fiocruz.br/ descentralizar/anexos/Aids_NOTA\%20T\%C3\%89CNICA\%20CASAS\%20DE\%20AP OIO\%5D.doc. Acesso: 13 maio 2006.

Galvão J. 1980-2001: resposta à Aids no Brasil. Rio de Janeiro: Associação Brasileira Interdisciplinar de Aids; 2002.

Galvão J. Aids e ativismo: o surgimento e a construção de novas formas de solidariedade. In: Parker R, Bastos C, Galvão J, organizadores. A AIDS no Brasil: 1982-1992. 2. ed. Rio de Janeiro: Relume-Dumará; 1994.

Galvão J. As respostas das organizações não-governamentais brasileiras frente à epidemia de HIV/Aids. In: Parker R, organizador. Políticas, instituições e Aids: enfrentando a epidemia no Brasil. Rio de Janeiro: J. Zahar; 1997.

Gohn MG. O novo associativismo e o terceiro setor. Serviço Social \& Sociedade. 1998;19(58):9-23.

Goldim JR. Manual de iniciação à pesquisa em saúde. 2. ed. rev. e ampl. Porto Alegre: Dacasa; 2000.

Granjeiro A. O perfil socioeconômico dos casos de Aids da cidade de São Paulo. In: Parker R, Bastos C, Galvão J, organizadores. A AIDS no Brasil: 1982-1992. 2. ed. Rio de Janeiro: Relume-Dumará; 1994. p. 91-125. 
Guerra MAT. Política de controle da Aids da Secretaria de Estado da Saúde de São Paulo, no período de 1983-1992: a história contada por seus agentes [dissertação]. São Paulo: Faculdade de Medicina da Universidade de São Paulo;1993.

Hartz ZMA, Silva LMV, organizadores. Avaliação em saúde: dos modelos teóricos à prática na avaliação de programas e sistemas de saúde. Salvador: EDUFBA; 2005.

IBGE.Cidades@. Disponível em: http://www.ibge.gov.br. Acesso: 2 abr. 2006.

Junqueira LAP. Descentralização e intersetorialidade: a construção de um modelo de gestão municipal. Revista de Administração Pública. 1998;32(2):11-22.

Junqueira LAP. A gestão intersetorial das políticas sociais e o terceiro setor. Saúde e Sociedade. 2004; 13(1):25-36.

Landim L. Notas para um perfil das ONGs. 1996. Disponível em: http://www.abong.org.br/ artigos/landim.htm. Acesso em: 6 nov. 2001.

Laurell AC. La política de salud en el contexto de las políticas sociales. In: Congresso Latinoamericano de Ciencias Sociales Y Medicina, 4., 1997. Cocoyoc (México); 1997.

Martins GA. Manual para elaboração de monografias e dissertações. 2. ed. São Paulo: Atlas; 1994.

Mattos RA, Terto Junior V, Parker R. As estratégias do Banco Mundial e a resposta à Aids no Brasil. Rio de Janeiro: Associação Brasileira Interdisciplinar de Aids; 2001. Disponível em: www.abiAids.org.br. Acesso: 14 abr. 2006.

Meny I, Thoenig JC. Las políticas públicas. Barcelona: Ariel; 1992.

Montaña C. Terceiro setor e questão social: crítica ao padrão emergente de intervenção social. São Paulo: Cortez; 2002.

Nogueira MA. Sociedade civil, entre o político-estatal e o universo gerencial. Revista Brasileira de Ciências Sociais. 2003;18(52):185-202. Disponível em: http://www.scielo.br/scielo.php?script=sci_arttext\&pid=S0102-69092003000200010 \&1ng=em\&nrm=isso. Acesso: 2 jan. 2006. 
Oliveira WF, Junqueira LAP. Questões estratégicas na reforma sanitária: desenvolvimento do terceiro setor. Revista de Administração Pública. 2003;37(2):227-42.

Parker R. A construção da solidariedade: AIDS, sexualidade e política no Brasil. Rio de Janeiro: Relume Dumara; 1994.

Programa Nacional de DST e AIDS 2002. AIDS - política brasileira de Aids principais resultados e avanços - 1994 a 2002. Brasília, 2002.

Programa Nacional de DST e AIDS 2004. AIDS. Boletim Epidemiológico. 2003;17(1):1-52.

São Paulo (Estado). Secretaria de Estado da Saúde. Coordenação dos Institutos de Pesquisa. Centro de Vigilância Sanitária. Centro de Referência e Treinamento DST/AIDS. Portaria conjunta 2CVS/CRT - DST/AIDS, de 28 de novembro de 2001. São Paulo; 2001.

Soares LTR. Ajuste neoliberal e desajuste social na América Latina. Rio de Janeiro: UFRJ; 1999. p. 337-354.

Teixeira PR. Políticas públicas em Aids. In: Parker R, organizador. Políticas, instituições e Aids: enfrentando a epidemia no Brasil. Rio de Janeiro: J. Zahar; 1997.

Venosa SS. A morte presumida no novo código civil. Disponível em: http://www.passarelliassessoria.com.br. Acesso: 10 nov. 2003.

Viana ALDA. Abordagens metodológicas em políticas públicas. Revista de Administração Pública. 1996;30(2):5-43.

Viana ALD’A. Novos riscos, a cidade e a intersetorialidade das políticas públicas. Revista de Administração Pública. 1998;32(2):23-33.

Víctora CG, Knauth DR, Hassen MNA. Pesquisa qualitativa em saúde: uma introdução ao tema. Porto Alegre: Tomo Editorial; 2000.

WORLD HEALTH ORGANIZATION. AIDS Epidemic Update: December 2002. Disponível em: http://www.who.int/hiv/pub/epidemiology/epi2002/en/. Acesso: 10 abr. 2006. 


\title{
ANEXO A - CADASTRO DE INSTITUIÇÕES DE APOIO SOCIAL - CASA DE APOIO, PASSAGEM E ABRIGO
}

\author{
CADASTRO DE INSTITUIÇÕES DE APOIO SOCIAL - \\ CASAS DE APOIO, PASSAGEM E ABRIGO
}

\section{INTRODUÇÄO:}

Existem atualmente no pais inúmeras organizações, dos mais variados cunhos, que desenvolvem iniciativas de apoio social voltadas aos individuos vivendo com HIV e aids. Variam desde simples iniciativas que nasceram de familiares de pessoas vivendo com o HIV/aids até instituições complexas, que mantêm por vezes várias organizações. e que têm em comum o oferecimento de serviços que visam melhorar e garantir a qualidade de vida destas pessoas.

Com o intuito de mapear a existência destas organizações no pais, para que haja maior visibilidade na sociedade com relação ás oportunidades de apoio social, e de promover o estabelecimento de uma rede interativa destas organizaçooes que possa atuar de forma integrada e complementar às ações governamentais, a Coordenação Nacional de DST e Aids elaborou este instrumento que tem por objetivo o cadastramento, por meio das Coordenações Estaduais e Municipais de DST/Aids, das instituições de apoio social ao portador de HIV e aids e seus familiares no pais.

O preenchimento deste formulário deve ser realizado de forma ciara e objetiva, levando-se em consideração a situação real da instituiçāo, ja que naao se trata de instrumento de fiscalização ou supervisăo, mas de fonte de levantamento das necessidades e das formas de cooperaçăo e investimentos necessários para que as instituições funcionem de forma a atender às necessidades e especificidades desta população.

E de especial importância que o instrucional para preenchimento deste questionário seja cuidadosamente observado, para que sejam evitados erros de preenchimento que facilmente levariam a uma análise equivocada da situação.
\end{abstract}

IDENTIFICACÃO
( ) CASA DE APOIO
( ) CASA DE PASSAGEM
( ) ABRIGO

Nome da instituição:

CNPJ: ' - - - - -

Endereço:

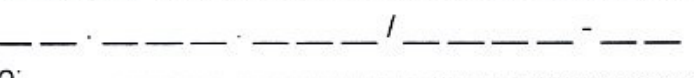

Cidade

Estado

CEP

Telefone:

$-$

Fax: ( )

E-mail:

Responsável:

CASO ESTEJA VINCULADA A OUTRA INSTITUIÇÃO:

Nome da instituição a que está vinculada:

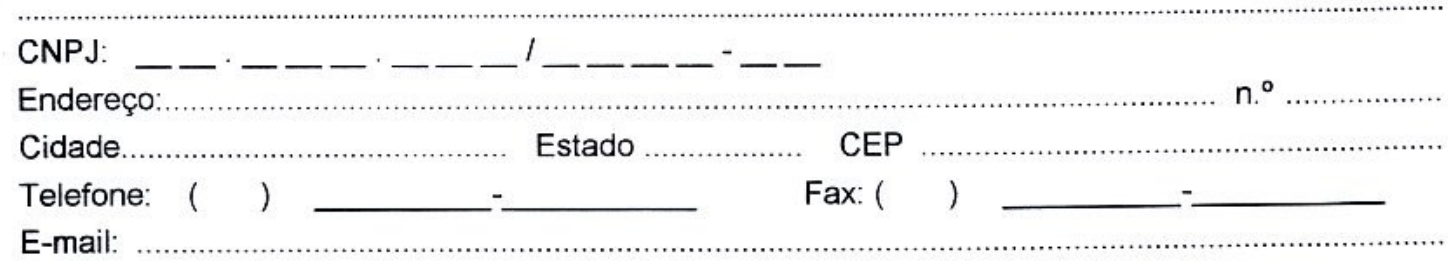

Responsável:.

Esta instituição mantém outra(s) instituição(ōes)/casa(s)? Qual?(Quais?) 
ORGANIZACCÃO JURIDICO-ADMINISTRATIVA

1. Situação juridica:

(1) Fundação

( 2 ) Organização da Sociedade Civil

( 3 ) Organização da Sociedade Civil de Interesse Público

( 4 ) Organização Governamental

( 5 ) Outras. Especificar:

2. Possui registro junto ao:

( 1 ) Conselho Municipal de Saúde

( 2 ) Conselho de Assistência Social

( 3 ) Conselho da Criança e do Adolescente

( 4 ) Não possui registro junto a conselhos

3. Forma de organização:

( 1 ) Por Estatuto

( 2 ) Por Regimento Interno/ Regulamento

( 3 ) Outras. Especificar:

4. Possui registro de Utilidade Pública:
( 1 ) Não
( 2 ) Sim
( 3 ) Federal
(4) Estadual ( 5 ) Municipal

5. Quantidade e vinculo da equipe responsável pelas atividades cotidianas:

\begin{tabular}{|l|l|l|l|}
\hline & Voluntários & Contratados & Cedidos \\
\hline 1. Médico/a & & & \\
\hline 2. Enfermeiro/a & & & \\
\hline 3. Psicólogo/a & & & \\
\hline 4. Psiquiatra & & & \\
\hline 5. Assistente social & & & \\
\hline 6. Odontólogo/a & & & \\
\hline 7. Auxiliar/técnico/a de enfermagem & & & \\
\hline 8. Cozinheiro/a & & & \\
\hline 9. Auxiliar de cozinha & & & \\
\hline 10. Faxineiro/a & & & \\
\hline 11. Lavadeira & & & \\
\hline 12. Motorista & & & \\
\hline 13. Outros. Especificar: & & & \\
\hline & & & \\
\hline & & & \\
\hline
\end{tabular}


6. Posse de veiculo(s):

( 1 ) $\mathrm{Sim} \rightarrow$ Número:

Tipo:

( 2 ) Não $\rightarrow$ Solução para necessidades de transporte no dia-a-dia (compras, transporte de usuarios, etc.)

(3) Taxi (4) Veiculo de pessoa que trabalha na instituição

( 5 ) Ônibus

( 6 ) Ajuda de vizinhos

( 7 ) Outros. Especificar:

7. Condicão de utilização do imóvel:
( 1 ) Próprio
( 2 ) Alugado
( 3 ) Público
( 4 ) Privado cedido

( 5 ) Outra. Especificar

8. Área construida

9. OBSERVACĀO DO ENTREVISTADOR: Conservaç̃o do Imóvel -

( 1 ) Precária

( 2 ) Aceitáve

( 3 ) Boa

( 4 ) Excelente

10. Fonte(s) de recursos:

( 1 ) Coordenação Nacional de DST e Aids

( 2 ) Outros Órgãos do Governo Federal

( 3 ) Governo Estadual

( 4 ) Governo Municipal

( 5 ) Exterior $\rightarrow$ Pais: Tipo:

Nome

( 6 ) Produção comercial dos usuários/moradores

( 7 ) Contribuições financeiras dos usuários/moradores (aposentadorias, auxilios-doença, familiares, outros)

( 8 ) Doações/convênios com pessoas jurídicas

( 9 ) Doações de pessoas físicas

(10) Eventos para arrecadação de fundos, inclusive bazares e brechós

(11) Outros. Especificar:

11. Principal fonte de recursos

12. Média mensal de gastos (últimos 6 meses) em R\$

13. Receita média mensal (últimos 6 meses) em R\$

\section{POPULAÇÃO ATENDIDA}

14. Média mensal de pessoas atendidas nos últimos 6 meses

15. Número de pessoas atendidas segundo tipo de permanência e período médio de permanência:

\begin{tabular}{|l|l|l|l|l|l|}
\hline \multicolumn{1}{|c|}{$\begin{array}{c}\text { Tipo de } \\
\text { Permanência }\end{array}$} & \multirow{2}{*}{$\begin{array}{l}\text { Total de } \\
\text { pessoas }\end{array}$} & \multicolumn{4}{|c|}{ Permanência média } \\
\cline { 3 - 6 } & & $\begin{array}{l}\text { Menos de } \\
\text { 1 semana }\end{array}$ & $\begin{array}{l}\text { De 7 a } \\
\text { 13 dias }\end{array}$ & $\begin{array}{l}\text { De 14 } \\
\text { a 20 dias }\end{array}$ & $\begin{array}{l}\text { De 21 a } \\
\text { 30/31 dias }\end{array}$ \\
\hline (1) Integral & & & & & \\
\hline (2) Pernoite & & & & & \\
\hline (3) Diuma & & & & & \\
\hline (4) Passagem & & & & & \\
\hline
\end{tabular}


16. Populaçăo atendida por gënero:
(1) Masculino
( 2 ) Feminino
(3) Ambos

17. População atendida por idade:
( 1 ) Adultos: de anos até anos
( 2 ) Crianças: de anos até anos
( 3 ) Adolescentes: de anos até anos

18. Fopulaçōes especificas atendidas:
( 1 ) Usuários de drogas
( 2 ) Travestis
( 3 ) População de rua
( 4 ) Pessoas com transtornos mentais
( 5 ) Profissionais do sexo
( 6 ) Alcoolistas
( 7 ) Homossexuais
( 8 ) Outros. Especificar:

19. População atendida segundo estado sorológico:

(1) Todos são soropositivos

(2) Nem todos são soropositivos $\rightarrow$ Média mensal de HIV+ atendidos nos últimos 6 meses

20. População atendida segundo local de moradia:

( 1 ) Apenas deste municipio

( 2 ) Deste e de outros municipios do estado

( 3 ) Deste município, de outros municípios do estado e de outros estados

21. Formas de encaminhamento dos usuários:
( 1 ) Justiça
( 2 ) Polícia
( 3 ) Hospitais
( 4 ) Espontâneo
( 5 ) Bombeiros
( 6 ) Unidades básicas de saúde
( 7 ) Outras. Especificar

22. Permissão para permanência/alojamento temporário dos acompanhantes/familiares soronegativos para o HIV $\begin{array}{ll}\text { ( } 1 \text { ) } \operatorname{Sim} & \text { ( } 2 \text { ) Não }\end{array}$

23. Critérios para desligamento das crianças/adolescentes:

( 1 ) Idade. Especificar

( 2 ) Soronegativação

( 3 ) Outros. Especificar

24. Critérios para desligamento dos adultos:

\section{BENEFICIOS OFERECIDOS}

25. Apoio às necessidades do dia-a-dia:

( 1 ) Abrigo diurno

( 2 ) Abrigo notumo $\rightarrow$ Número de leitos

( 3 ) Todas as refeições

(4) Algumas refeições

( 5 ) Administração de medicamentos

(6) Encaminhamento (transporte) para exames laboratoriais e consultas

( 7 ) Instalaçöes e materiais relacionados à higiene pessoal

( 8 ) Outros. Especificar 
26. Atendimentos de saúde:

(9) Consultas Médicas

(10) Consultas Odontológicas

(11) Consultas de Psicologia

(12) Consultas de Psiquiatria

(13) Outras consultas. Especificar

27. Atividades dirigidas para a promoção da qualidade de vida dos usuários:

( 14 ) Informação, educação, capacitação

( 15 ) Inserção social e familiar

( 16 ) Inserção no mercado de trabalho

(17) Profissionalização

(18) Assessoria juridica

(19) Atividades de artesanato e afins

(20) Atividades fisicas

( 21 ) Lazer

( 22 ) Apoio/Procedimentos para adoção

(23) Outras. Especificar

28. Atividades de estimulo à adesão ao tratamento:

( 1 ) Não são desenvolvidas

( 2 ) São desenvolvidas: $\rightarrow$ ( 3 ) Individualmente $(4)$ Coletivamente

29. Permissão para visitas:

( 2 ) Não ( 1 ) Sim-Critérios:

30. Permissão para saidas:

( 2 ) Não ( 1 ) Sim-Critérios:

\section{OUTRAS INFORMAC̄ÕES}

31. A Casa mantém intercâmbio (troca de experiências, encaminhamento de usuários, repasse de excedente de doações) com outra(s) instituições?
( 2 ) Não
( 1 ) Sim. Especificar: 
32. Principais dificuldades identificadas:

( 1 ) Adesão ao tratamento

( 2 ) Relação com os usuários

( 3 ) Relação entre os usuários

( 4 ) Número insuficiente de profissionais especializados

( 5 ) Equipe necessita maior capacitação

( 6 ) Insuficiência de recursos humanos

( 7 ) Falta de equipamentos

( 8 ) Falta de materiais de consumo (medicamentos, material para curativos, material de limpeza, higiene. alimentos, etc.)

( 9 ) Falta de transporte próprio para realizar atividades de rotina

(10) Outras. Especificar:

33. Existe algum tipo de avaliação externa (supervisão) por órgão financiador ou outro? ( 2 ) Não ( 1 ) Sim. Especificar:

Responsável pelo preenchimento do questionário:

Função:

Data:

Entrevistador:

Outras instituições de apoio que conhece, mesmo que apenas de ouvir falar (Nome, endereço, telefone - 0 mais completo possivel): 


\section{ANEXO B - COMITÊ DE ÉTICA}

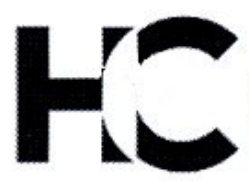

\section{Mosphnd UhS Gumbas \\ DA FACULDKALE DE MEDICURS}

\section{APROVACEÃO}

A Comissão de Ética para Análise de Projetos de Pesquisa - CAPPesq da Diretoria Clínica do Hospital das Clínicas e da Faculdade de Medicina da Universidade de São Paulo, em sessão de 13.04.05, APROVOU o Protocolo de Pesquisa $n^{\circ}$ 105/05, intitulado: "Das Casas de Apoio ao apoio às Casas - Análise do processo de formulação e implementação das políticas públicas de saúde para as DST/HIV/Aids no Estado de São Paulo no período de 1996 a 2003" apresentado pelo Departamento de MEDICINA PREVENTIVA.

Cabe ao pesquisador elaborar e apresentar à CAPPesq, os relatórios parciais e final sobre a pesquisa (Resolução do Conselho Nacional de Saúde ${ }^{\circ} 196$, de 10.10.1996, inciso IX.2, letra "c").

Pesquisador(a) Responsável: Prof. Dr. Heráclito Barbosa de Carvalho Pesquisador(a) Executante: Sra. Ciomara de Freitas Gonçalves

CAPPesq, 13 de Abril de 2005.

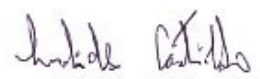

PROF. DR. EUCLIDES AYRES DE CASTILHO

Presidente da Comissão de Ética para Análise de Projetos de Pesquisa

\footnotetext{
Comissão de Ética para Análise de Projetos de Pesquisa do HCFMUSP e da FMUSP Diretoria Clínica do Hospital das Clínicas da Faculdade de Medicina da Universidade de São Paulo Rua Ovídio Pires de Campos. 225, $5^{\circ}$ andar - CEP 05403010 - Sđo Paulo - SP 
ANEXO C - QUADROS DE VARIÁVEIS E INDICADORES

\begin{tabular}{|c|c|c|}
\hline Objetivo & Variáveis & Indicadores \\
\hline $\begin{array}{l}\text { 1.Caracterizar as } \\
\text { chamadas Casas de Apoio } \\
\text { do Estado de São Paulo } \\
\text { segundo tipos de } \\
\text { financiamento, } \\
\text { modalidades de gestão e } \\
\text { níveis de assistência. }\end{array}$ & $\begin{array}{l}\text { 1.1 - Fontes de financiamento } \\
\text { das Casas de Apoio } \\
1.2 \text { - Modelos de gestão } \\
1.3 \text { - Modalidades de assistência } \\
1.4 \text {-Tempo de atuação }\end{array}$ & $\begin{array}{l}\text { 1.1.1- Formas de composição das } \\
\text { fontes (financiamentos internacionais, } \\
\text { públicos, privados, pessoa física, } \\
\text { jurídica, outras parcerias) } \\
\text { 1.2.1 - Grau de profissionalização } \\
\text { (cargos, assessorias, uso de } \\
\text { tecnologia de informação, controle de } \\
\text { custos e gastos, outros) } \\
\text { 1.3.1 - Natureza dos serviços } \\
\text { prestados e perfil dos assistidos } \\
\text { 1.4.1 - Tempo de existência. }\end{array}$ \\
\hline
\end{tabular}




\begin{tabular}{|c|c|c|}
\hline Objetivo & Variáveis & Indicadores \\
\hline $\begin{array}{l}\text { 2. Identificar e analisar a } \\
\text { articulação intersetorial entre a } \\
\text { Secretaria Estadual da Saúde e } \\
\text { demais Secretarias Estaduais, } \\
\text { com organizações da sociedade } \\
\text { civil ligadas ao movimento de } \\
\text { luta contra Aids e com os } \\
\text { organismos internacionais, na } \\
\text { formulação e implementação de } \\
\text { políticas públicas para as } \\
\text { DST/HIV/Aids, bem como } \\
\text { identificar as formas de } \\
\text { representação das Casas de } \\
\text { Apoio. }\end{array}$ & 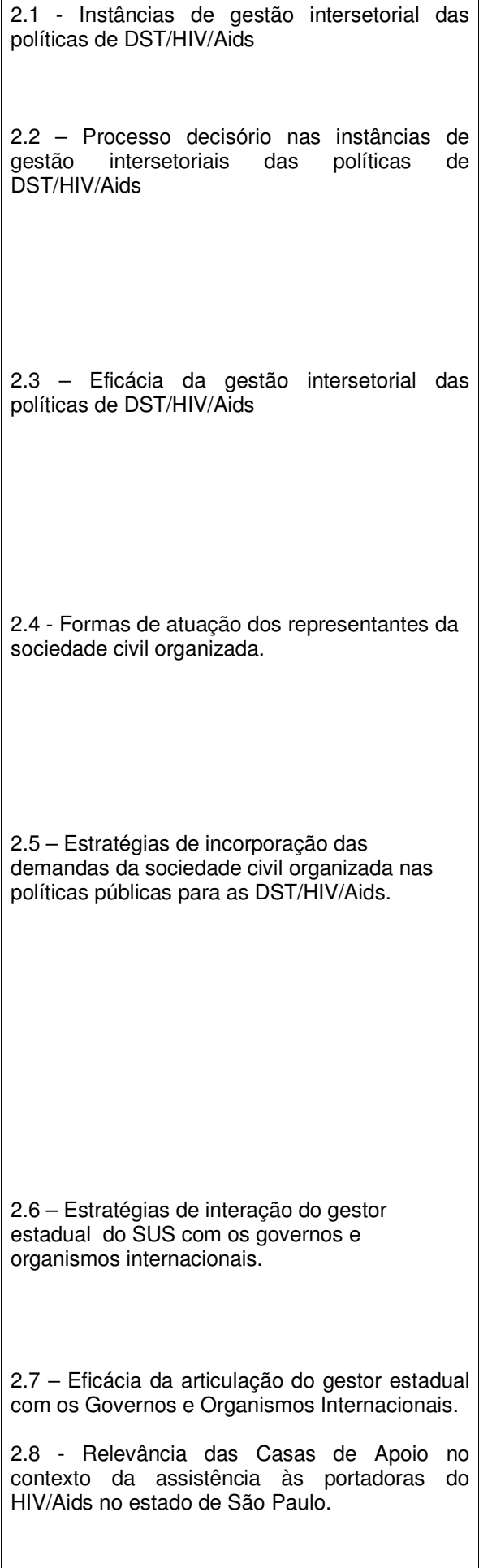 & 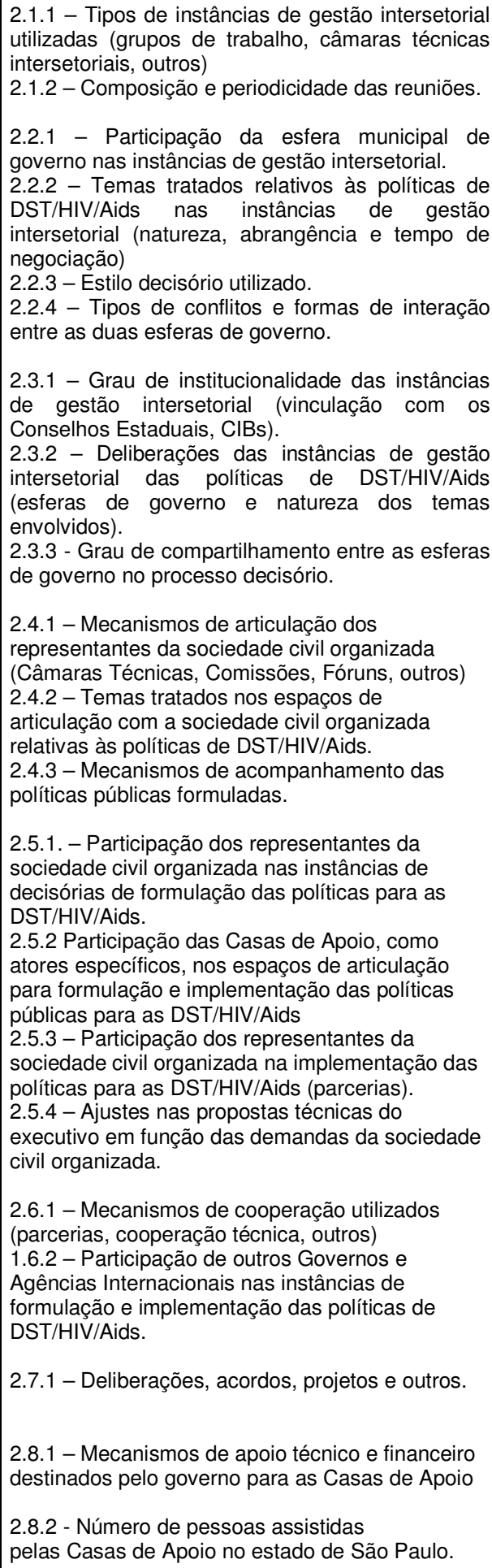 \\
\hline
\end{tabular}




\section{ANEXO D - ROTEIRO DE ENTREVISTA}

\section{Roteiro de Entrevista}

Identificar e analisar a articulação intersetorial entre a Secretaria Estadual da Saúde e demais Secretarias Estaduais, com organizações da sociedade civil ligadas ao movimento de luta contra Aids e com os organismos internacionais, na formulação e implementação de políticas públicas para as DST/HIVIAids, bem como identificar as formas de representação das Casas de Apoio.

Instâncias de gestão intersetorial das políticas de DST/HIVIAids

1. Que tipos de instâncias de gestão intersetorial são utilizadas (grupos de trabalho, câmaras técnicas intersetoriais, outros) no processo de formulação das politicas de DSTAids?

2. Qual a composição e periodicidade das reuniöes?

Processo decisório nas instâncias de gestão intersetoriais das políticas de DST/HIVIAids

Qual a participação da esfera municipal de governo nas instâncias de gestão intersetorial?

1. Quais temas tratados são relativos às políticas de DST/HIVIAids nas instâncias de gestäo intersetorial (natureza, abrangência e tempo de negociação)?

2. Qual o estilo decisório utilizado?

3. Que tipos de conflitos e formas de interação existe entre as duas esferas de governo?

Eficácia da gestão intersetorial das políticas de DST/HIVIAids

1. Qual o grau de institucionalidade das instâncias de gestão intersetorial (vinculação com os Conselhos Estaduais, CIBs)?

2. Quais são as deliberações das instâncias de gestão intersetorial das políticas de DST/ HIVIAids (esferas de governo e natureza dos temas envolvidos)?

3. Qual o grau de compartilhamento entre as esferas de governo no processo decisório?

Formas de atuação dos representantes da sociedade civil organizada.

1. Quais os mecanismos de articulação dos representantes da sociedade civil organizada (Câmaras Técnicas, Comissões, Fóruns, outros)? 
2. Quais são os temas tratados nos espaços de articulação com a sociedade civil organizada relativas às políticas de DST/HIVIAids?

3. Quais são os mecanismos de acompanhamento das políticas públicas formuladas?

Estratégias de incorporação das demandas da sociedade civil organizada nas políticas públicas para as DST/HIVIAids.

1. Qual a participação dos representantes da sociedade civil organizada nas instâncias de decisórias de formulação das políticas para as DST/HIVIAids?

2. Qual a participação das Casas de Apoio, como atores específicos, nos espaços de articulação para formulação e implementação das políticas públicas para as DST/HIVIAids?

3. Como se dá a participação dos representantes da sociedade civil organizada na implementação das políticas para as DST/HIVIAids (parcerias)?

4. São feitos ajustes nas propostas técnicas do executivo em função das demandas da sociedade civil organizada?

Estratégias de interação do gestor estadual do SUS com os governos e organismos internacionais.

1. Quais são os mecanismos de cooperação utilizados (parcerias, cooperação técnica, outros) entre o Programa Estadual de DSTIAids e os organismos internacionais?

2. Há registro de participação de outros Governos e Agências Internacionais nas instâncias de formulação e implementação das políticas de DST/HIVIAids?

Eficácia da articulação do gestor estadual com os Governos e Organismos Internacionais.

1. Quais são as deliberações, acordos, projetos e outros, decorrentes da articulação entre o Estado de São Paulo e os organismos internacionais?

Relevância das Casas de Apoio no contexto da assistência às portadoras do HIVIAids no estado de São Paulo.

1. Quais são os mecanismos de apoio técnico e financeiro destinados pelo governo especificamente para as Casas de Apoio?

2. Qual o número de pessoas assistidas pelas Casas de Apoio no estado de São Paulo. 
ANEXO E - TERMO DE CONSENTIMENTO LIVRE E ESCLARECIDO

\author{
FACULDADE DE MEDICINA DA USP - DEPTO. MEDICINA PREVENTIVA \\ Termo de consentimento pós-informação para grupo focal com profissionais
}

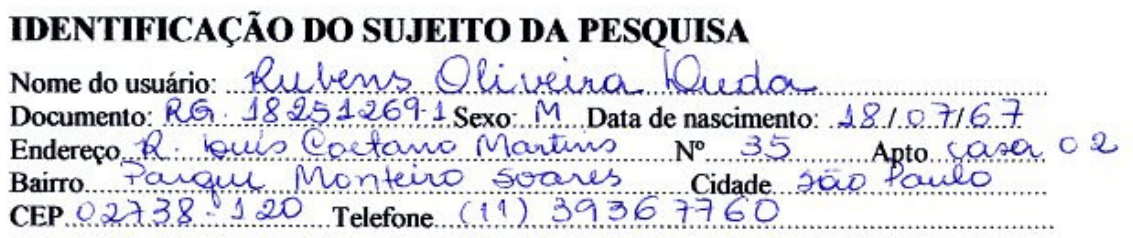

\title{
DADOS SOBRE A PESQUISA CIENTÍFICA
}

A Faculdade de Medicina da Universidade de São Paulo está desenvolvendo um projeto para identificar e analisar a rede de apoio social criada no processo de implementação das políticas públicas de DST/HIV/Aids no Estado de São Paulo e as articulações intersetoriais presentes nessas politicas. Com os seguintes objetivos: Caracterizar as Casas de Apoio em HIV/Aids do Estado de São Paulo segundo tipos de financiamento, modalidades de gestão e niveis de assistência; identificar e analisar a articulação intersetorial entre a Secretaria Estadual da Saúde e as demais Secretarias Estaduais, com organizaçōes da sociedade civil ligadas ao movimento de luta contra a aids e com os organismos internacionais, na formulação e implementação das políticas públicas para as DST/HIV/Aids, bem como as formas de representação das Casas de Apoio.

O titulo da pesquisa é: "Das casas de Apoio ao apoio das Casas - Análise do processo de formulação e implementação deas politicas de saúde para as DST/HIV/Aids no Estado de São Paulo no periodo de 1996 a 2003", que tem como pesquisador responsável Heráclito Barbosa de Carvalho e como pesquisadora executante Ciomara de Freitas Gonçalves.

É uma pesquisa com a duração de um ano e que não tem riscos para os participantes.

\section{PARTICIPAÇÃO DOS VOLUNTÁRIOS CONVIDADOS}

Pedimos sua colaboração para a realização do estudo através da participação em um grupo focal que dura mais ou menos uma hora e meia. No grupo focal será valorizada a sua experiência em trabalhar com AIDS e suas opiniões e reflexöes sobre as atividades dos serviços que atendem pessoas vivendo com HIV e AIDS. A discussão será gravada.

GARANTIAS DO SUJEITO DA PESQUISA

É importante que você saiba que as informações obtidas poderão ser utilizadas para publicação, mas os entrevistados ou serviços mencionados não serão identificados na análise e publicação do material obtido. Cabe esclarecer também que os profissionais individualmente não são objeto de nenhum tipo de avaliação. As informaçōes que você der durante a entrevista, em hipótese nenhuma, prejudicarão o seu trabalho ou inserção na unidade. Você também poderá interromper sua participação na pesquisa no momento que desejar, sem nenhum problema.

INFORMAÇÕES SOBRE OS RESPONSÁVEIS PELO ACOMPANHAMENTO DA PESQUISA, PARA CONTATO.

Se você tiver dúvidas sobre esta pesquisa ou sobre sua participação, sinta-se à vontade para perguntar agora ou em qualquer momento, ao pesquisador responsável.

\section{CONSENTIMENTO PÓS-ESCLARECIDO}

Declaro que, após ter sido convenientemente esclarecido pelo pesquisador e ter entendido o que me foi explicado, consinto em participar da pesquisa

Data

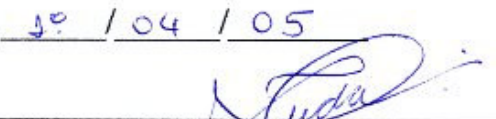

assinatura do participante do grupo focal

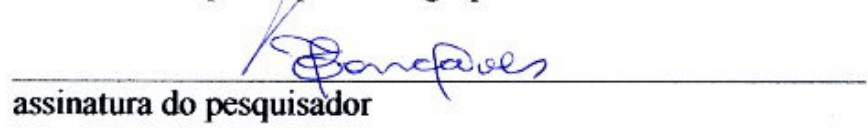




\section{FACULDADE DE MEDICINA DA USP - DEPTO. MEDICINA PREVENTIVA}

Termo de consentimento pós-informação para gestores e especialistas em AIDS com experiência em serviços

\section{IDENTIFICAÇÃO DO SUJEITO DA PESQUISA}

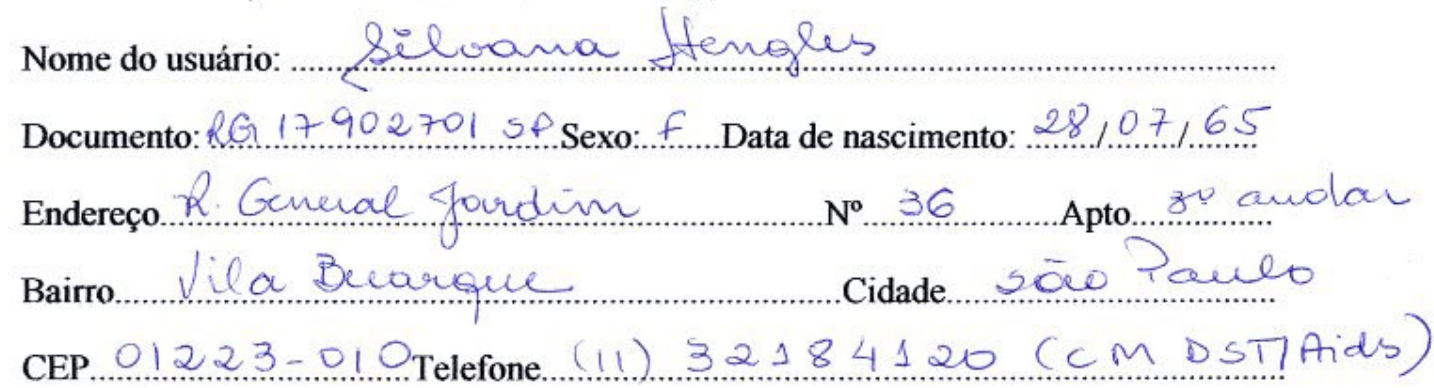

\section{DADOS SOBRE A PESQUISA CIENTÍFICA}

A Faculdade de Medicina da Universidade de São Paulo está desenvolvendo um projeto para identificar e analisar a rede de apoio social criada no processo de implementação das políticas públicas de DST/HIV/Aids no Estado de São Paulo e as articulações intersetoriais presentes nessas politicas. Com os seguintes objetivos: Caracterizar as Casas de Apoio em HIV/Aids do Estado de São Paulo segundo tipos de financiamento, modalidades de gestão e niveis de assistência; identificar e analisar a articulação intersetorial entre a Secretaria Estadual da Saúde e as demais Secretarias Estaduais, com organizações da sociedade civil ligadas ao movimento de luta contra a aids e com os organismos internacionais, na formulação e implementação das políticas públicas para as DST/HIV/Aids, bem como as formas de representação das Casas de Apoio.

O título da pesquisa é: "Das casas de Apoio ao apoio das Casas - Análise do processo de formulação e implementação das políticas de saúde para as DST/HIV/Aids no Estado de São Paulo no periodo de 1996 a 2003”, que tem como pesquisador responsável Heráclito Barbosa de Carvalho e como pesquisadora executante Ciomara de Freitas Gonçalves.

\section{É uma pesquisa com a duração de um ano e que não tem riscos para os participantes.}

\section{PARTICIPAÇÃO dOS VOLUNTÁRIOS CONVIDADOS}

Pedimos sua colaboração para a realização do estudo através da participação em um grupo focal que dura mais ou menos uma hora e meia. No grupo focal será valorizada a sua experiência em trabalhar com AIDS e suas opiniões e reflexões sobre as atividades dos serviços que atendem pessoas vivendo com HIV e AIDS. A discussão será gravada.

\section{GARANTIAS DO SUJEITO DA PESQUISA}

É importante que você saiba que por se tratar de profissionais com reconhecida experiência os seus nomes constarão dos agradecimentos. Por ocasião da divulgação da pesquisa, as opiniões e reflexões sobre parâmetros e indicadores de qualidade da assistência emitidas no grupo constarão da publicação. Você também poderá interromper sua participação na pesquisa no momento que desejar, sem nenhum problema. 


\section{INFORMAÇÕES SOBRE OS RESPONSÁVEIS PELO ACOMPANHAMENTO DA PESQUISA, PARA CONTATO.}

Se você tiver dúvidas sobre esta pesquisa ou sobre sua participação, sinta-se à vontade para perguntar agora ou em qualquer momento, ao pesquisador responsável.

\section{CONSENTIMENTO PÓS-ESCLARECIDO}

Declaro que, após ter sido convenientemente esclarecido pelo pesquisador e ter entendido o que me foi explicado, consinto em participar da pesquisa

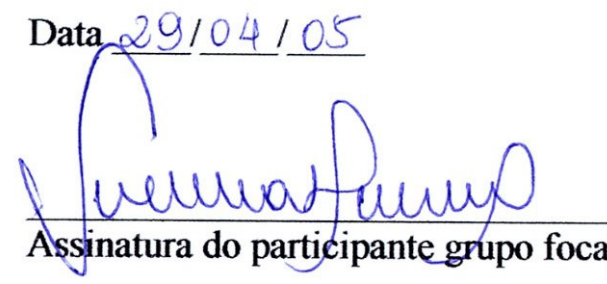

$\frac{\text { Eonoques }}{\text { Assinatura do pesquisador }}$ 


\title{
FACULDADE DE MEDICINA DA USP - DEPTO. MEDICINA PREVENTIVA
}

\author{
Termo de consentimento pós-informação para gestores e especialistas em AIDS com
} experiência em serviços

\section{IDENTIFICAÇÃo dO SUJEITO DA PESQUISA}

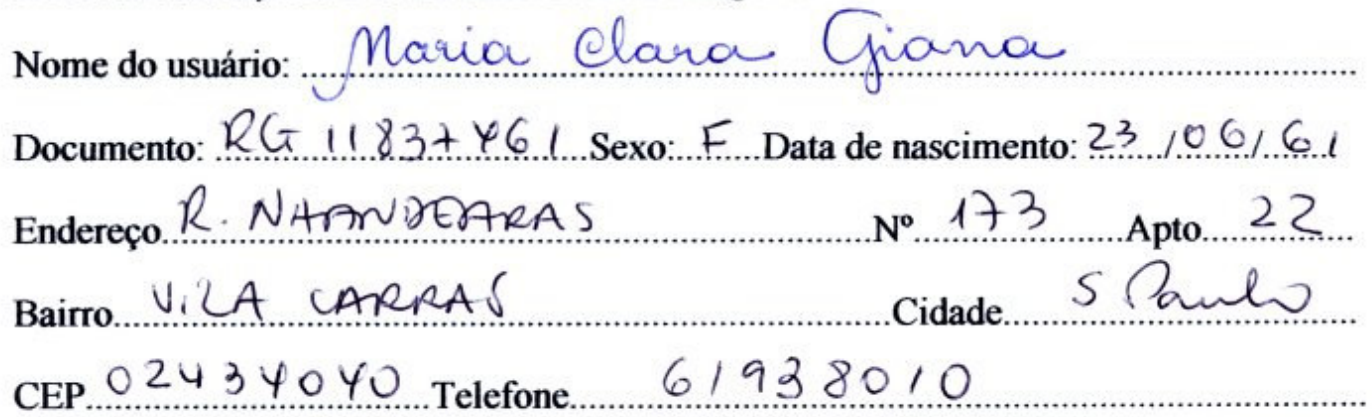

\section{DADOS SOBRE A PESQUISA CIENTÍFICA}

A Faculdade de Medicina da Universidade de São Paulo está desenvolvendo um projeto para identificar e analisar a rede de apoio social criada no processo de implementação das políticas públicas de DST/HIV/Aids no Estado de São Paulo e as articulações intersetoriais presentes nessas políticas. Com os seguintes objetivos: Caracterizar as Casas de Apoio em HIV/Aids do Estado de São Paulo segundo tipos de financiamento, modalidades de gestão e níveis de assistência; identificar e analisar a articulação intersetorial entre a Secretaria Estadual da Saúde e as demais Secretarias Estaduais, com organizações da sociedade civil ligadas ao movimento de luta contra a aids e com os organismos internacionais, na formulação e implementação das políticas públicas para as DST/HIV/Aids, bem como as formas de representação das Casas de Apoio.

O título da pesquisa é: "Das casas de Apoio ao apoio das Casas - Análise do processo de formulação e implementação das politicas de saúde para as DST/HIV/Aids no Estado de São Paulo no periodo de 1996 a 2003", que tem como pesquisador responsável Heráclito Barbosa de Carvalho e como pesquisadora executante Ciomara de Freitas Gonçalves.

É uma pesquisa com a duração de um ano e que não tem riscos para os participantes.

\section{PARTICIPAÇÃO DOS VOLUNTÁRIOS CONVIDADOS}

Pedimos sua colaboração para a realização do estudo através da participação em um grupo focal que dura mais ou menos uma hora e meia. No grupo focal será valorizada a sua experiência em trabalhar com AIDS e suas opiniões e reflexões sobre as atividades dos serviços que atendem pessoas vivendo com HIV e AIDS. A discussão será gravada.

\section{GARANTIAS DO SUJEITO DA PESQUISA}

É importante que você saiba que por se tratar de profissionais com reconhecida experiência os seus nomes constarão dos agradecimentos. Por ocasião da divulgação da pesquisa, as opiniões e reflexões sobre parâmetros e indicadores de qualidade da assistência emitidas no grupo constarão da publicação. Você também poderá interromper sua participação na pesquisa no momento que desejar, sem nenhum problema. 


\section{INFORMAÇÕES SOBRE OS RESPONSÁVEIS PELO ACOMPANHAMENTO DA PESQUISA, PARA CONTATO.}

Se você tiver dúvidas sobre esta pesquisa ou sobre sua participação, sinta-se à vontade para perguntar agora ou em qualquer momento, ao pesquisador responsável.

\section{CONSENTIMENTO PÓS-ESCLARECIDO}

Declaro que, após ter sido convenientemente esclarecido pelo pesquisador e ter entendido o que me foi explicado, consinto em participar da pesquisa

Data $29,04,05$

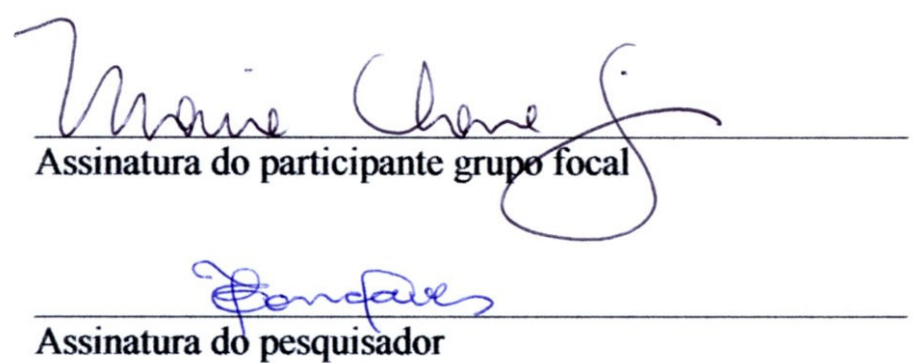

